\title{
STARRY TWINS AND MYSTERY RITES: FROM SAMOTHRACE TO MITHRAS
}

\begin{abstract}
Summary: Iconographic analogies between the Mithraic torchbearers, Cautes and Cautopates, and the Greek Dioscuri encourage a comparative analysis of these figures in context. Previous studies have emphasized the potential for the divine twins to be the origins of the torchbearers: a closer examination of the Dioscuri as they functioned within another mystery cult, the rites of the Great Gods of Samothrace, offers light on both the phenomenology of initiation and the cultural context common to both the Greek and the Roman rituals. Among the numerous visual and conceptual parallels, the strongest commonality between the two sets of youths is a cultural appetite for astral mysticism, which connects the late Republican Roman voices on Samothrace and the later world of the Mithraic caves. The two mysteries served, however, profoundly different functions with respect to Roman identity - a dynamic which the parallel presence of twinned, framing shining lights reveals.
\end{abstract}

Key words: Cautes, Cautopates, torchbearers, Samothrace, comparative studies, Dioscuri, torches, Varro, Nigidius Figulus

\section{INTRODUCTION: COMPARING THE INCOMPARABLE? ${ }^{1}$ MITHRAS AND THE MYSTERIES}

Mithraic studies are in many ways sui generis among the approaches to mystery cults in ancient Rome. Though situated in an empire with rich literary traditions, Mithras has no texts to compare to Apuleius' novel of Isis, Livy's account of Cybele, the senatus consultum against Bacchus, or the Greek hymnic traditions for Eleusis. ${ }^{2}$ The result has been an especially central role for the interpretation of archaeological spaces and

${ }^{1}$ With apologies to DetIENNE, M.: Comparing the Incomparable. Tr. J. Lloyd. Stanford 2008.

${ }^{2}$ Apuleius, Golden Ass; Livy 29. 10-14; for available texts on Mithras, see HANNAH, R.: The Image of Cautes and Cautopates in the Mithriac Tauroctony Icon. In Dillon, M. P. J. (ed.): Religion in the Ancient World: New Themes and Approaches. Amsterdam1996, 177-192, here 179 n. 3; MEYER, M. W.: The Ancient Mysteries: A Sourcebook of Sacred Texts. Philadelphia 1999, 197-222. 
images. ${ }^{3}$ The distinctiveness and great geospatial distribution of that material made a massive catalogue the first step in investigation, and established Cumont and Vermaseren as the founding fathers of Mithraic studies. An apparent closeness with army camps encouraged investigative frameworks far removed from civic or imperial cult. ${ }^{4}$ Evidence of Persian origins, detected through both etymology and iconography, made familiarity with Iranian studies a complex desideratum. ${ }^{5}$ The evidence for zodiacal and astronomical content in the rituals linked their study to the challenging specializations of ancient astronomy, and the astral mysticism hinted at in the writings of Porphyry, Celsus and the Mithras liturgist. ${ }^{6}$ The rituals of Mithras, as a result, have been pursued through scholarly categories and specializations as unique as the rites themselves appear to have been.

Mithras shares, however, one significant commonality with other mystery religions: a problematic relationship with comparative studies. Three tendencies stand out. The first is the use of comparanda to establish historical origins, which has encouraged a focus on similarities rather than distinctions. ${ }^{7}$ The second is the long hegemony of comparisons with Christianity, in which the narrative of the church triumphant downplayed attention to local contexts. ${ }^{8}$ The third is the inclusion of Mithraism among the 'oriental religions' of Rome, a category constructed out of generalizing stereotypes from the 19 th century. ${ }^{9}$ There has been a reduction in comparative approaches to mystery cults in general, and with rare exceptions this has also been the fate of Mithras. ${ }^{10}$

${ }^{3}$ HANNAH (n. 2) 3; BECK, R.: Mithraism since Franz Cumont. ANRW II.17.4 (1984) 2002-2115, here 2057; BECK, R.: The Mithraic Torchbearers and 'Absence of Opposition'. Echos du monde classique 26.1 (1982) 126-140; BECK, R.: Planetary Gods and Planetary Orders in the Mysteries of Mithras. Leiden 1987; VOLLKOMMER, R.: Mithras Tauroctonus. Studien zu einer Typologie der Stieropferszene auf Mithrasbildwerken. MEFR 103 (1991) 265-281; VOLLKOMMER, R. in LIMC 6.1 (1992) 583-626, s.v. 'Mithras'.

${ }^{4}$ SPEIDEL, M.: Mithras-Orion: Greek Hero and Roman Army God. Leiden 1980.

${ }^{5}$ Gordon, R. L.: From Mi $\theta \rho \alpha$ to Roman Mithras. In VevainA, Y. (ed.): The Wiley Blackwell Companion to Zoroastrianism. Chichester 2015, 451-455.

${ }^{6}$ CHAPMAN-RIETSCHI, P. A. L.: Astronomical Conceptions in Mithraic Iconography. Journal of the Royal Astronomical Society of Canada 91 (1997) 133-134; SwERDLOw, N. M.: Review Article: On the Cosmical Mysteries of Mithras. CP 86.1 (1991) 48-63, 51.

${ }^{7}$ SMith, J. Z.: Drudgery Divine: On the Comparison of Early Christianities and the Religions of Late Antiquity. Chicago 1990, 129: BECK, R.: Ritual, Myth, Doctrine and Initiation in the Mysteries of Mithras: New Evidence from a Cult Vessel. JRS 90 (2000) 145-180, 174.

${ }^{8}$ NABARZ, P.: The Mysteries of Mithras: The Pagan Belief that Shaped the Christian World. Rochester 2005; WinTER, E.: Mithraism and Christianity in Late Antiquity. In MitChell, S. - GrEATREX, G. (eds): Ethnicity and Culture in Late Antiquity. London 2000, 173-182; BURKERT, W.: Ancient Mystery Cults. Cambridge, MA 1987; SMITH (n. 7); LEASE, G.: Mithraism and Christianity: Borrowings and Transformations. ANRW II.23.2 (1980) 1306-1332; BETZ, H. D.: The Mithras Inscriptions of Santa Prisca and the New Testament. Novum Testamentum 10.1 (1968) 62-80.

${ }^{9}$ GORDON, R. L.: Coming to Terms with the "Oriental" Religions of the Roman Empire. Numen 61 (2014) 657-672; AlVAR EZQUERRA, J.: Romanising Oriental Gods: Myth, Salvation, and Ethics in the Cults of Cybele, Isis, and Mithras. Trans. R. Gordon. Leiden Brill 2008; MASTROCINQUE, A.: « L'oeuvre es. Et l'oeuvre sera ». Note panoramique sur les mystères de Mithra après Cumont. In BELAYCHE, N. MASTRocinQue, A. (edd): Franz Cumont: Les Mystères de Mithra. Rome 2013 lxix-xc.

${ }^{10}$ SPEIDEL (n. 4) 2; GORDON: Coming to Terms (n. 9) 663-666; EDMUNDS, R.: Did the Mithraists Inhale? A Technique for Theurgic Ascent in the Mithras Liturgy, the Chaldaean Oracles, and Some Mithraic Frescoes. Ancient World 32.1 (2000) 10-24 is a welcome exception. 
These factors exemplify the challenges of comparative studies in ancient Mediterranean contexts in which, as Detienne notes, the assumed uniqueness of the topic cultures has separated history from anthropology. ${ }^{11}$ Those anthropological approaches to comparison include the phenomenological, which foreground the ties between the experiential, the expressive and the understanding, and a focus on the cultural categories of the subjects. Cross-cultural comparisons are ultimately most productive for helping investigators separate themselves from their own etic perspectives, and see with fresh eyes the original context of their study. ${ }^{12}$ In this paper, I propose a comparative study that takes up these approaches, focused on Cautes and Cautopates in the Mithraic cult and the Dioscuri of Samothrace. Cumont was the first to propose a comparison between the Dioscuri, broadly identified, and the Mithraic pair; Ulansey, Hannah, and Beck, among others, have pursued the proposal at more length. Their work has built on evidence of shared astronomical functions, iconographic analogies, and a general function as framers of a divine drama. They have also foregrounded the scientific inconcinnities and imprecise visual analogies between the two sets of data. Responses to these results highlight the distance between the historical and the anthropological approaches to the rites: stern critiques from the historians of science, and calls for a recognition of ancient metaphor as 'unrestrictive, subtle, allusive and polyvalent'. ${ }^{13}$

The case study of Samothracian Dioscuri offers a comparative project attentive to these calls. As a mystery cult known to Romans as well as Greeks, Samothrace seems to counter Detienne's call for cross-cultural comparanda, and so surrender some of the heuristic potentials of comparative work. Indeed, the cult's genuinely Greek origins seem, at Rome, to dissolve in a flurry of claims for Roman ownership of the rites. The comparison is consistent, however, with anthropological norms in its attentiveness to indigenous cultural categories. The investigation yields a historical proposal, not for the origin and advent of the rites, but for how upper class Romans approached the mysteries, bringing to them the lenses of natural philosophy and an appetite for cosmic speculation. This naturalizes Cicero's observation that the mysteries had more to do with natural science than philosophy, and it reduces the apparent incomparability of Mithraic and other mystery celebrations. ${ }^{14}$ The comparison yields, as well, phenomenological insights into the firey associations of these figures, helping us close the gap between the lived experience of the cave and one of the most distinctive scholarly pathways in Roman religion.

${ }^{11}$ DetienNe (n. 1).

${ }^{12}$ AlLEN, D.: Phenomenology of Religon. In Hinnells, J. (ed.): The Routledge Companion to the Study of Religion. London 2005, 182-207; MURPHY, T.: The Politics of Spirit: Phenomenology, Genealogy, Religion. Albany 2010; cf. HINNELLS, J.: The Iconography of Cautes and Cautopates. I: The Data. JMS 1 (1976) 36-67 for the need to foreground the Roman context, ClaUSS, M.: The Roman Cult of Mithras: The Gods and His Mysteries. Trans. R. Gordon. New York 2000 on the benefits of approaching Mithras as ritual experience.

${ }^{13}$ BECK, R.: In the Place of the Lion: Mithras in the Tauroctony. In HinNELLS, J. R. (ed.): Studies in Mithraism. Rome 1994, 29-50, here 35.

${ }^{14}$ De Nat. Deor I 42. 119. 


\section{THE TORCHBEARERS: IMAGE, DISTRIBUTION AND TEXT}

The torchbearers appear from one end of the Roman empire to another, but their distribution is far from even. The bulk of their representations come from Central and Eastern Europe, especially Dacia and Pannonia; in Rome they are omitted from tauroctonies more often than they are included. ${ }^{15}$ They appear as a pair of young men, dressed in Persian-style caps and tunics. ${ }^{16}$ Their consistent function is the bearing of torches pointed in antithetical directions: Cautes' torch points up, Cautopates' down ${ }^{17}$ (fig. 1). Their legs are often crossed, in an apparent signal of relaxation. They wear clothing similar in style to Mithras, though in less sumptuous colors, and they are smaller in size than the god they attend. ${ }^{18}$ Inscriptions confirm their names as Cautes and Cautopates.

They frame a range of scenes, including the tauroctony, scenes of the rockbirth, or the taurophory, the 'bull hauling'. ${ }^{19}$ Hinnells notes that a full $70 \%$ of the latter scenes include at least one torchbearer, as do some $11 \%$ of all scenes of ritual meals. ${ }^{20}$ In addition to their torches, they may be associated with attributes including a pedum (shepherd's crook), cock, tree, bow, bull, corn ears, stick, krater, or scorpion. These distinguish them from Mithras, who bears only a torch. No single attribute, other than the raised torch, is typical of either figure throughout the empire, and few if any are associated with only one of the pair. ${ }^{21}$ Dacia has yielded the greatest evidence for these attributes, with Rome, Germany and Pannonia all tied for second; in no area do more than $47 \%$ of the depictions preserve them. ${ }^{22}$ Cautes and Cautopates appear on a range of surfaces, including cult reliefs, altars, votives, and cult paraphernalia such as ceramic wares. During the course of Mithraic celebration, a group member could make an offering on top of a torchbearer, hold one in the hand, or select him as the form and recipient of the vow to be fulfilled.

Their names have seemed Iranian in origin, and etymological studies since the 19 th century have explored possible Iranian roots as keys to their meaning and function. ${ }^{23}$ Other origins have been identified in Greek, Dacian, Etruscan and Avestan languages, with meanings including 'burn' 'fortune' 'ruler' 'plenty' and 'having wide pastures.' Schwartz' helpful survey concludes with a proposal focused on Old Iranian *kauta, meaning young, boy, small, or child, appropriate to their function as hypostases

${ }^{15}$ HinNELLS (n. 12); Beck: The Mithraic Torchbearers (n. 3).

${ }^{16}$ HANNAH (n. 2) 186-187.

${ }^{17}$ BECK: The Mithraic Torchbearers (n. 3); Clauss (n. 12) 96.

${ }^{18}$ Hinnells (n. 12) 50; HANnAH (n. 2) 183; BECK: Mithraism (n. 3) 2082-2083.

${ }^{19}$ Clauss (n. 12) 97.

${ }^{20}$ HinNELLS (n. 12) 46.

${ }^{21}$ The attributes do not intersect with Mithras, though he can bear a torch at his birth, see HINNELLS (n. 12) 50 .

${ }^{22}$ HinNeLLS (n. 12) 43.

${ }^{23}$ W. W. MALANDRA in Encyclopedia Iranica V 1 (London 1990) 95-96, s.v. "Cautes and Cautopates"; SchwarTZ, M.: Cautes and Cautopates, the Mithraic Torchbearers. In HinNELlS, J. R. (ed.): Mithraic Studies. Vol. II. Manchester 1975, 406-423, here 406, 413-422. 


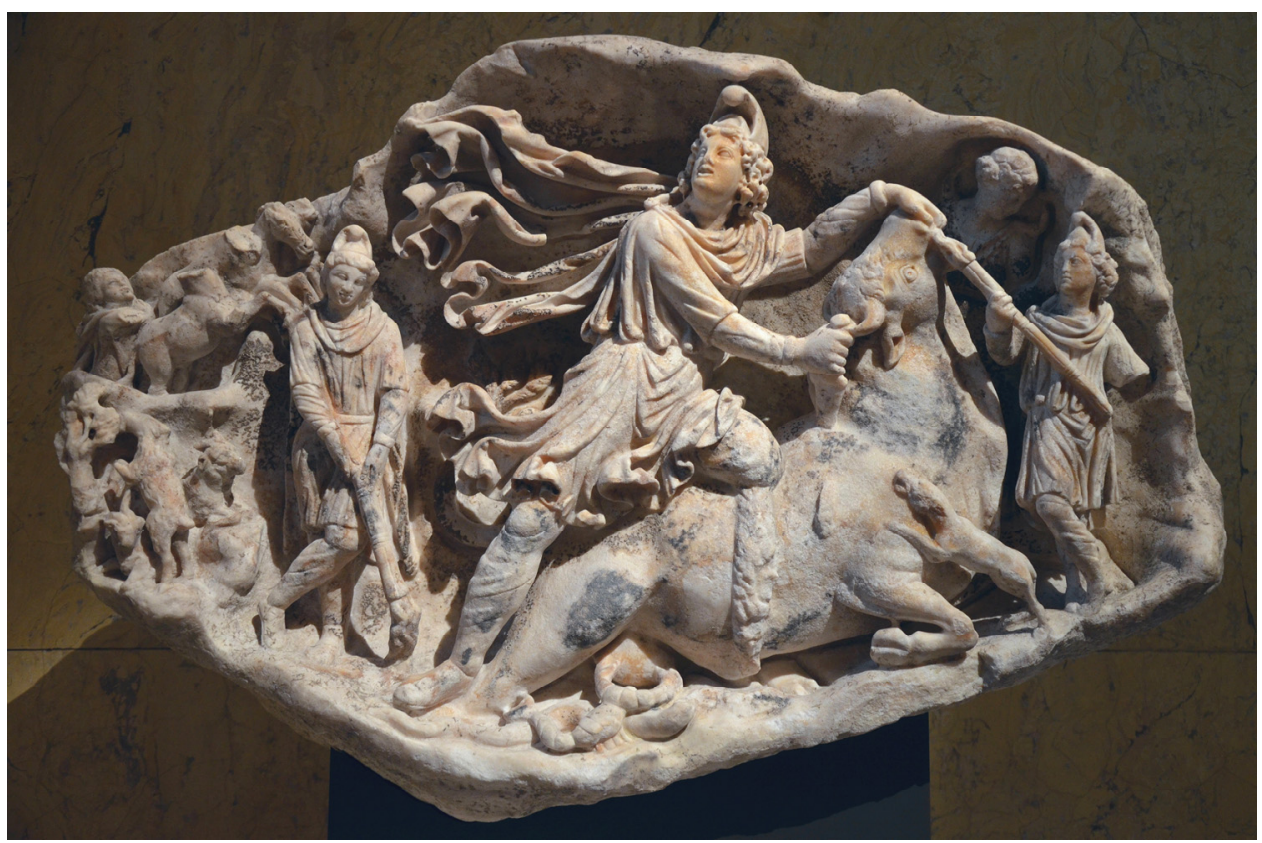

Fig. 1. Tauroctony, white marble, second half of 2nd century AD. Recovered south of Monastero near Aquileia. Kunsthistorisches Museum, Vienna. Photo courtesy of Carole Radatto

of Mithras himself. ${ }^{24}$ Beck cautions that there is no reason to suppose that initiates in Rome would have been aware of any of the etymological subtleties, or the meanings they implied. 25

Textual references to these figures are slender. The most direct is one of eighteen 2nd-century AD inscriptions from the Mithraeum below the church of Santa Prisca in Rome; the texts, at approximately equal distance from each other, are metrical in form, and may reflect the first lines of hymns or poems whose entire contents the initiates would have known.

\section{Fons concluse petris qui geminos aluisti nectare fratres}

Rockbound spring that fed the twin-brothers with nectar. ${ }^{26}$

Cumont and Vermaseren suggest that 'brothers' of this verse are the torchbearers, though a fraternal relationship between Cautes and Cautopates is not well attested. ${ }^{27}$

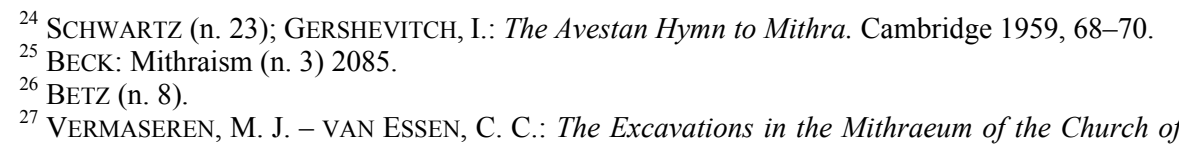
Santa Prisca in Rome. Leiden 1965, 71-74, 193-195; CUMONT, F.: Textes et Monuments figurés relatifs aux mysterès de Mithra. Vol. I-II. Brussells 1894-1896, I 164-166; MERKELBACH, R.: Mithras. Königstein 1984, 112-115; CLAUSS (n. 12) 69, 80-82; ALVAR EZQUERRA (n. 9) 86. 
The torchbearers are, however, known to appear in association with the water miracle, especially in the Rhine-Danube regions. ${ }^{28}$ They share with the brothers of this verse an association with a complex, nuanced range of symbols for the divine genesis of life. A more than human life force is signaled here first by the allusion to the water miracle, second by the substitution of nectar, a Latin double for ambrosia and a token of immortality. ${ }^{29}$ As a divine force springing from stone, that nectar may be argued to evoke Mithras himself, on whose birth the torchbearers attend, and to which an analogously over-determined cluster of symbols - including water, snakes, flowers or flame - may be appended. ${ }^{30}$ Allusive, polysemic and condensed, this single line positions the brothers around an act that evokes the miraculous birth of the god they most resemble. $^{31}$

\section{THE TORCHBEARERS AND THEIR SCHOLARS}

There are three points of general agreement for the meaning and function of Cautes and Cautopates: their relationship to Mithras, to light, and their arrangement as paired opposites. Cumont was the first to identify the pair as hypostases of Mithras, and noted their likely derivation from the conventions of figurative religious art, as two heraldically placed attendants on a major god. ${ }^{32}$ The term 'triformed Mithras', which appears in pseudo-Dionysius the Aereopagite (Epist. 7), seems a titular reference to the intimacy of this relationship. ${ }^{33}$ An alternative iconographic representation of their closeness comes from a relief panel from Dieburg, showing a tree with three branches, each ending in a head wearing a Phrygian cap (fig. 2). As Mithras is the sun, the torchbearers are symbols of light, and together with him represent the rising, high point and setting of the sun. A pair of altars dedicated by T. Martialius Candidus in Germania Superior, inscribed to D(eo) Oc(cidenti) and $\mathrm{D}(\mathrm{eo}) \mathrm{O}$ (rienti), exemplify this understanding. ${ }^{34}$

The principle of paired opposition seems central to the torchbearers: only a very few monuments depict the torchbearers making parallel gestures, with both torches raised or both lowered. ${ }^{35}$ Referents for that principle of opposition are identified

${ }^{28}$ CLAUSS (n. 12) 71-72 and fig. 4, a large altar at Poetovio on which is depicted one person standing before the rock face to catch the water in his cupped hands.

${ }^{29}$ Cic. Tusc 1. 26. 65; cf. de nat. deor. 1. 40. 112; Ovid, Metam. 3. 318; 10. 161; 14. 606; Horace, carm. 3. 2. 12.

${ }^{30}$ Clauss (n. 12) 67-68; BECK: Ritual (n. 7) 152; VERMASEREN, M. J.: The Miraculous Birth of Mithras. Mnemosyne 4th ser., 4.3-4 (1951) 285-301; the torchbearers attend the rock birth in a group at Dublin, and at Schwadorf in Austria, and Virunum, Pettausee.

${ }^{31}$ Vermaseren-VAN ESSEN (n. 27) 193; USENER, H.: Milch und Honig. In USENER, H. (ed.): Kleine Schriften: Vierter Band, Arbeiten zur Religionsgeschichte. Vol. IV. Leipzig-Berlin 1913, 398-417.

${ }^{32}$ BECK: Mithraism ( n. 3) 2084; Cumont: $M M M$ (n. 27) I 203-208; GERSHEVITCH (n. 24$) 151$.

${ }^{33}$ GersheVitch (n. 24) 70-71; CLAUSS (n. 12) 96.

${ }^{34}$ CIL XIII 11791a-b = V 1214-15: CLAUSS (n. 12) 95-97.

${ }^{35}$ Hinnells (n. 12): BeCK: The Mithraic Torchbearers (n. 3) cites, as exceptions, both torches up on Vermaseren, M. J.: Corpus Inscriptionum et Monumentorum Religionis Mithriacae [CIMRM]. The 


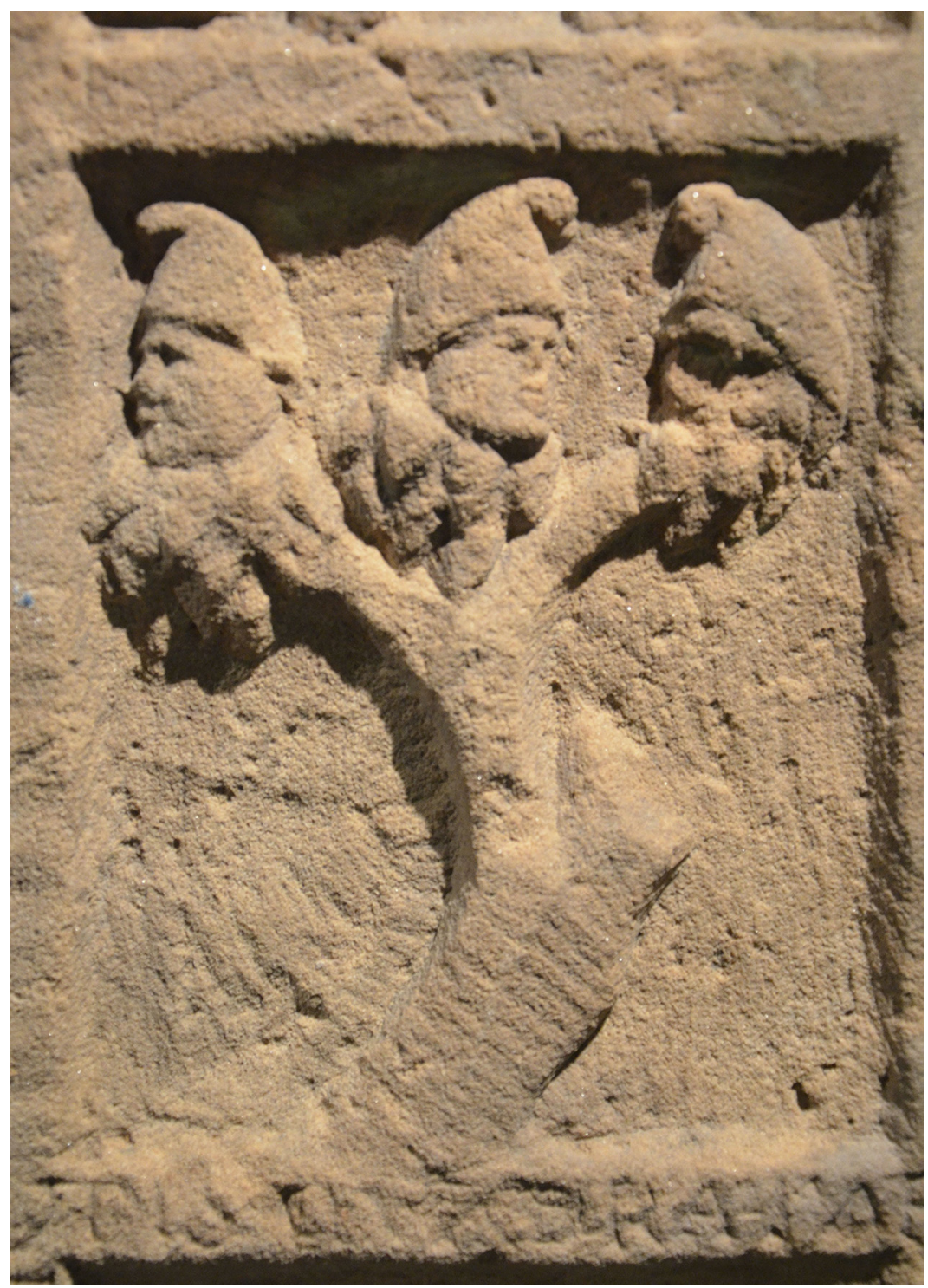

Fig. 2. Detail from Dieburg Mithraeum, Museum Schloss Fechenbach. Photo courtesy of Carole Radatto

across a range of celestial and natural phenomena: the rising and setting of the sun, the arrival of autumn and spring, heat and cold, growth and decay, sprouting and harvest, the summer and winter solstices, the spring and fall equinoxes, and ascending

Hague 1956, 606 (possibly a modern restoration), 616, 1452, 1468, 1472, 2001, 2180; both torches down on 1704 and 2171 . 
and descending nodes, where the moon's path intersects that of the sun. They may also be aligned with the cardinal directions east and west. ${ }^{36}$

\section{CONSTELLATIONS}

There is far less concensus regarding the identification of the torchbearers with constellations: proposals include Libra, Gemini, Cancer, Capricorn, Taurus and Scorpio. Hannah notes the appeal of Gemini, as the major, clearly visible constellation visible in the zodiac between Taurus and Scorpius, but omitted from the tauroctony. ${ }^{37}$ The absence of Persian garb or torches from any of the Gemini's familiar iconography, however, mitigates against the proposal. Porphyry's exegesis of Homer - de Antro Nympharum - is the basis for suggesting Cancer and Capricorn as the torchbearer's astral avatars.

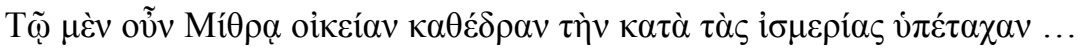

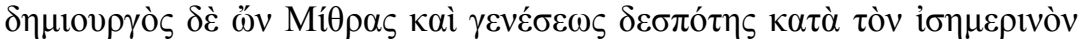

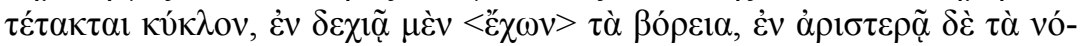

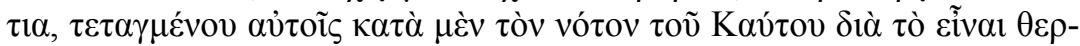

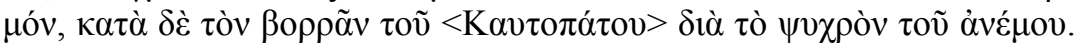

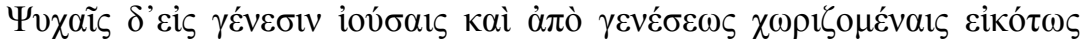

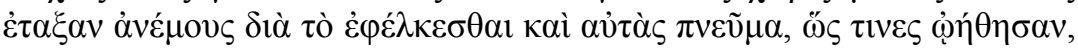

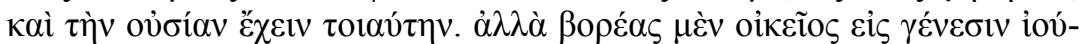
oais.

The equinoctial region they assigned to Mithras an appropriate seat... As a creator and lord of genesis, Mithras is placed in the region of the celestial equator with the north to his right and the south to his left; to the south, because of its heat, they assigned Cautes and to the north $<$ Cautopates $>$ because of the coldness of the north wind.... the north wind is the proper wind for souls proceeding to genesis....since it is colder, [it] congeals life and in the chill of earthly genesis locks it in, while the latter, since it is warmer, dissolves it and impels it upwards to the heat of the divine.

The Arethusa edition of the text restores the names Cautes and Cautopates to the passage, associating Cautopates with Cancer, and Cautes with Capricorn. ${ }^{38}$ More significantly, this ties the pair with the processes of human genesis and apogenesis which Mithras controls from his seat at the equinoxes, making them his avatars in functional as well as iconographic form. The route of the stars becomes metaphoric for

\footnotetext{
${ }^{36}$ BECK: The Mithraic Torchbearers (n. 3) 126; BECK: In the Place (n. 13) 33.

${ }^{37}$ HANNAH (n. 2) 184-185; BeCK: In the Place (n. 13) 33; CHAPOUTHIER, F.: Les Dioscures au sevice d'une déesse, étude d'iconographie religieuse. Paris 1935, 256, 306.

38 BECK: The Mithraic Torchbearers (n. 3) 127; BECK, R.: Interpreting the Ponza Zodiac. JMS 2 (1978) 87-147, 90 n. 10; Arethusa edition, Buffalo 1969.
} 
the journey of the human soul, and the torchbearers are tied into a soteriological interpretation of the Mithraic experience. ${ }^{39}$

Ulansey proposes an identification with Taurus and Scorpius, based on attributes of the torchbearers in Dacia and in Rome. In votive statues offered by Sytheus in the Mithraeum in Sarmizegetusa in Dacia, Cautopates holds a scorpion in his left hand, his legs crossed; the torch is now broken off, but traces of red color are visible ${ }^{40}$ (fig. 3). Cautes mirrors his counterpart in his dress and pose, and holds a bull's head in his left hand. These attributes appear again in the iconography of the Mithraeum from the house of Octavian Zeno in Rome ${ }^{41}$ (fig. 4). Here the tauroctony is framed by two panels: on the right, a leafing tree bears a bull's head suspended from its branches and a gigantic raised torch across its trunk, appropriate for Spring and for Cautes. On the left, a scorpion and a lowered torch, appropriate for Cautopates and autumn, appear alongside a tree in fruit. These zodiacal associations, Ulansey proposes, associate Cautes and the bull's head with the spring equinox when life is bursting forth; Cautopates, with scorpio, represents the autumn equinox. The focus on terrestrial bloom is appropriate for the Mithraeum's owner, who descended from a long line of Roman farmers. The Mithraeum's inscription describes his family's craft in Mithraic terms:

Qui assiduo labore, die noctuque, tribus solis, quattuor lunae stationibus, et naturali utrusque sideris cursu observatis, fortitudine, providentia, fide, et diligentia, terram fatigando rem agranam tractat et proinde carum frugum quae lucis in tenebrarum tempore creantur, oriuntur, excolunturque uberrimum pioventum fert.

he overcame the land through constant labor, night and day, through the three watches of the sun and four of the moon.....and thus bears the most fertile and beloved of the fruits which are created, cultivated, and born at once into the light from the darkness.

Ulansey argues that the identification of the torchbearers with Taurus and Scorpio would also align them with the equinoxes. This contradicts their position in GrecoRoman times, but would have been consistent with the skies as they appeared between 4000-2000 BC, a result of the precession of the equinoxes. The bridge between the Greco-Roman world and these ancient skies is provided by Hipparchus of Nicaea who, in the 2nd century BC, recognized the principle of precession. The Stoic philosophers of Tarsus could have seized upon this notion, made it the core of their astronomical mysteries, and communicated it to the pirates who, according to Plutarch (Pompey 24), brought the rites of Mithras to the west.

\footnotetext{
${ }^{39}$ BECK: Mithraism ( n. 3) 2085.

${ }^{40}$ Ulansey, D.: The Origins of the Mithraic Mysteries: Cosmology and Salvation in the Ancient World. Oxford 1989, 50-51, 62; CIMRM 2120, 2122.

${ }^{41}$ CIMRM 335.
} 

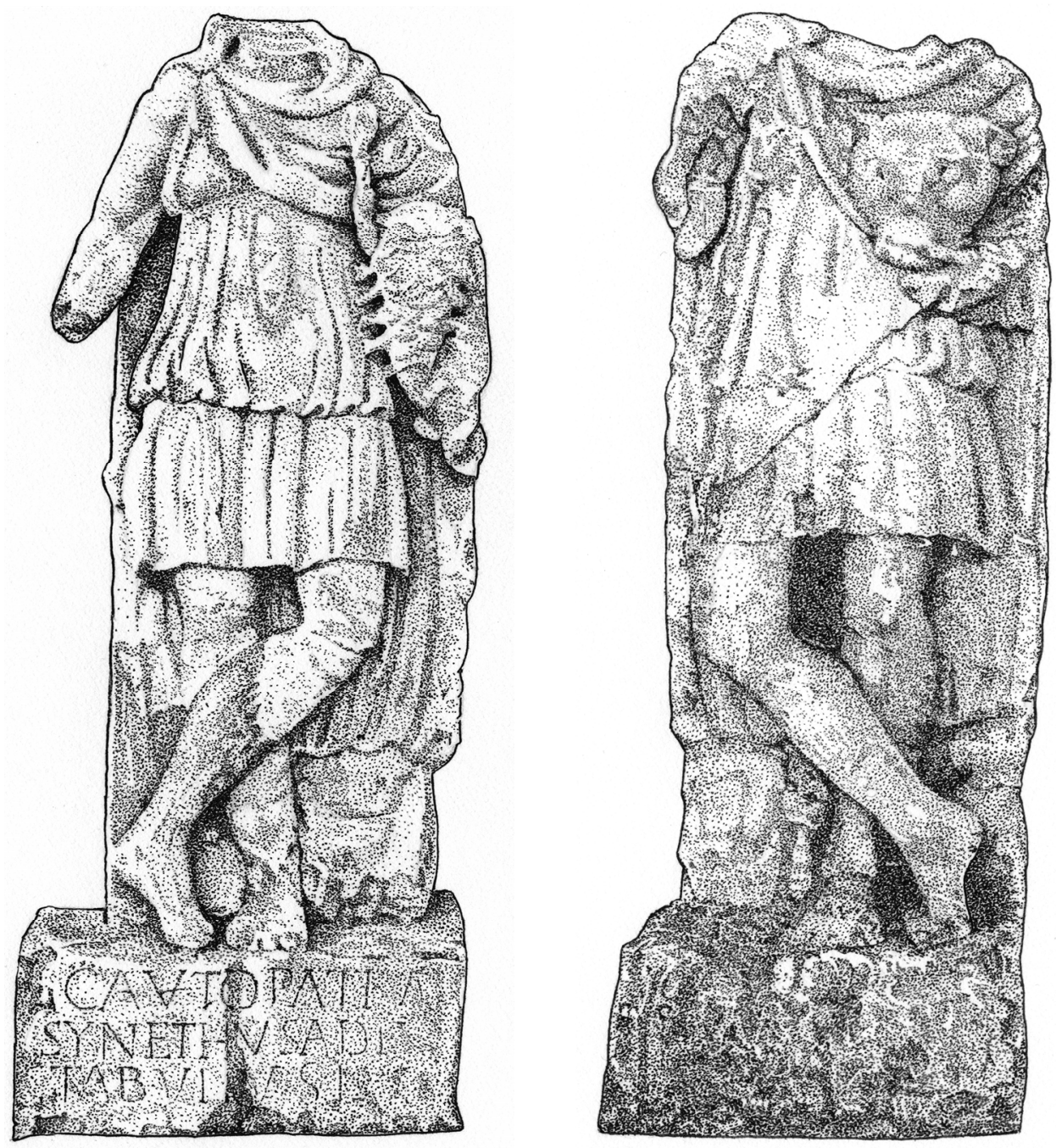

Figs 3a-b. Named statues of Cautopates and Cautes, Sarmizegetusa, Romania (CIMRM 2120, 2122). Illustrations by Martiti Camp Mundy

\section{TORCHBEARERS AND DIOSCURI: COMPARISON, ORIGINS AND CONTEXT}

These astrological proposals for the torchbearers, combined with iconography, have provided a foundation for comparison between Cautes, Cautopates and the Dioscuri. Ulansey used these to seek an origin for the Mithraic figures; Beck places these in more specific ancient contexts, toward a more nuanced interpretation. The Dioscuri were long identified as the two halves of the celestial sphere. When Philo Judaeus describes 


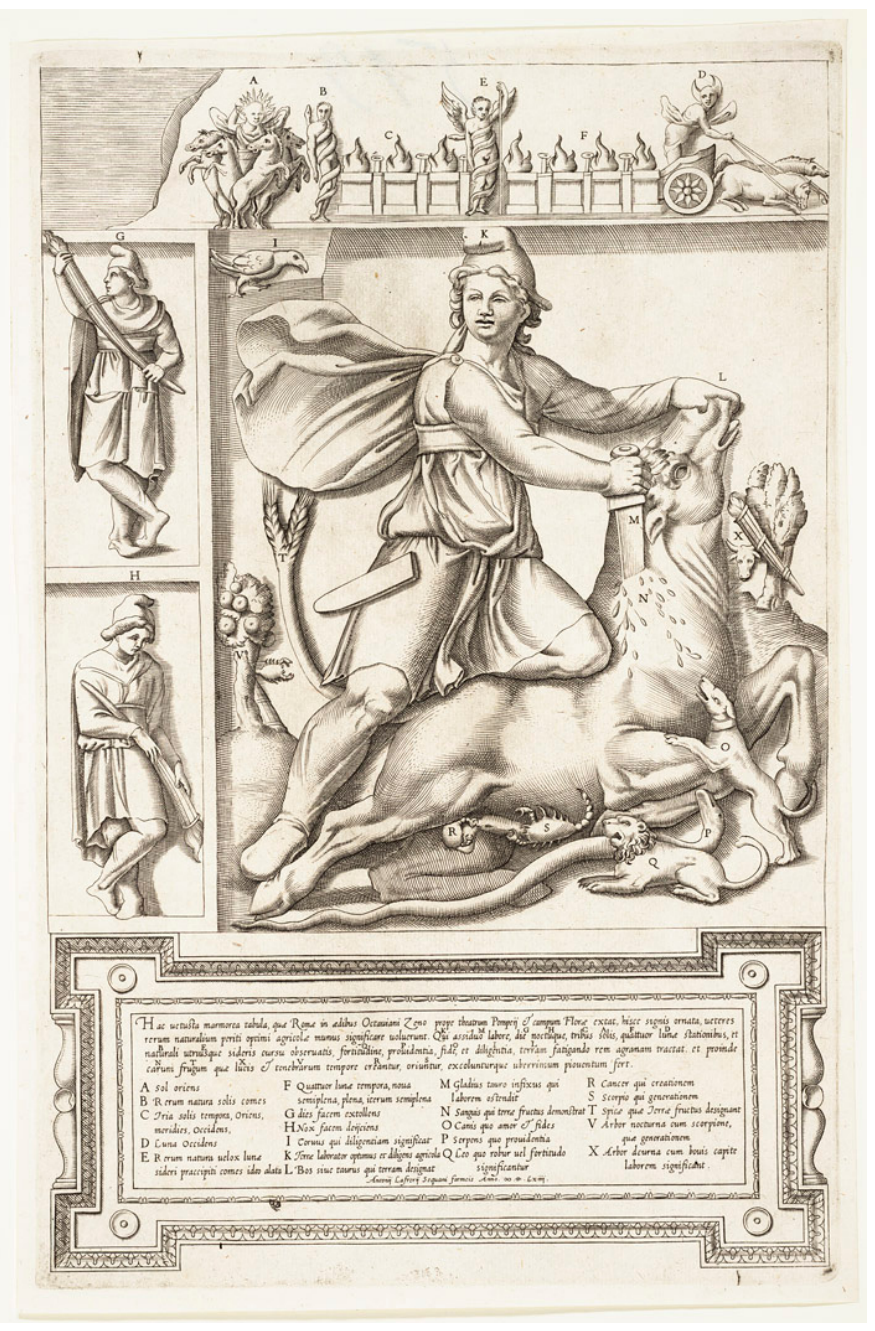

Fig. 4. Tauroctony of Ottavio Zeno, Rome (CIMRM 335). Drawing from Speculum Romanae Magnificentiae, Special Collections, University of Chicago Library

them as such, he refers to the 'mythmakers' who knew these ideas. ${ }^{42}$ The concept carries on long after Philo, appearing in the writings of Sextus Empiricus, John of Lydia, and the Neoplatonic Damascius. ${ }^{43}$ Philo writes

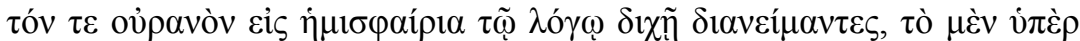

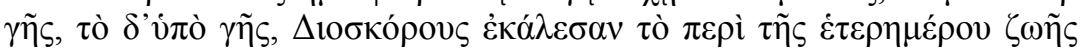

${ }^{42}$ Philo, On the Decalogue 55-57; UlANSEY (n. 40) 114.

${ }^{43}$ Sextus Empiricus, Adv. Math. 9. 37, 2nd-3rd century AD: Ioannes Lydos, de mensibus IV 17, 5th-6th century AD; cf. Damask. Quaest. de prim. princip. 261, 5th-6th century AD. 


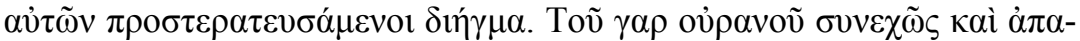

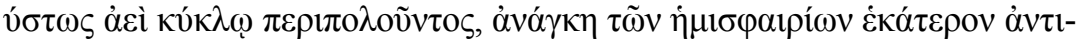

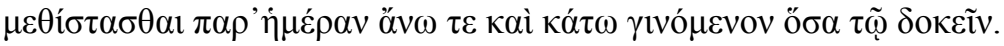

So too in accordance with the theory by which they divided the heaven into the two hemispheres, one above the earth and one below it, they called them the Dioscuri and invented a further miraculous story of their living on alternate days. For indeed as heaven is always revolving ceaselessly and continuously round and round, each hemisphere must necessarily alternately change its position.

Philo suggests that the mythmakers - masters of inventive tales - linked the natural science, speculative model of the universe with a charming mythological tale of brotherly affection. ${ }^{44}$ That affection has cosmic manifestation on a daily level, as the revolution of the heavens he describes is meant to refer to the alternation of night and day ( $\dot{\varepsilon \varepsilon \rho \eta \mu \varepsilon ́ \rho o v) . ~ E m p e r o r ~ J u l i a n ~ w o u l d ~ n o t e, ~ i n ~ t h e ~ f o u r t h ~ c e n t u r y, ~ t h a t ~ t h i s ~ m o v e-~}$ ment could also refer to the seasonal shifts at spring and fall, appropriate for their positions at the equinoxes. ${ }^{45}$ Ulansey notes iconographic support of these celestial conceptions in ancient interpretations of the Dioscuri's caps as the two halves of an egg. ${ }^{46}$ At the comic level, the egg is the one from which they themselves hatched; at the cosmic, it becomes the Orphic egg from which the universe emerges, a notion Cumont associates with the Pythagoreans. ${ }^{47}$

Further iconographic parallels link the torchbearers and the sons of Zeus. Cautes and Cautopates wear caps which, like those of the Dioscuri, are distinctive in shape and may stand as their sign, pars pro toto; both may also be represented metonymically as stars. ${ }^{48}$ Both of them function as framing figures - the Dioscuri around a divine female, the torchbearers around the tauroctony. And even their physical pose may recall each another. Dioscuri depicted on Hellenistic Etruscan mirrors stand in a relaxed pose, heraldically positioned on either side of a connecting beam which renders them 'dokana'. A number of these mirrors show them with legs crossed, in direct analogy to Cautes and Cautopates. A limestone relief of the 1st-3rd centuries CE from Vienne preserves two Dioscuri positioned around a standing Aion, who clutches a key to his breast; the better preserved of the young men wears the Phrygian cap and

${ }^{44}$ Cf. Philo's discussion of their affection in The Embassy to Gaius 84-85.

${ }^{45}$ Ulansey (n. 40) 115: Julian, Hymn to King Helios 147A-B, WrIGHT, W.C.: The Works of the Emperor Julian. Vol. I. Cambridge 1962, I 401-403.

${ }^{46}$ GuARducCI, M.: Le insegne dei Dioscuri. Archeologia Classica 36 (1984) 133-154, here 138.

${ }^{47}$ Cumont, F.: Recherches sur le Symbolisme Funéraire des Romains. Paris 1942, 70; Pliny, NH 2. 7. 17; Lucian, Dialogi deorum 26; Aristophanes, Birds 695.

${ }^{48}$ Clauss (n. 12) 49 and fig 9; 95 fig 45; CIMRM 1902; UlANSEY (n. 40) 112 notes that celebrants in the Mithraeum at Jajce in Dalmatia physically encountered this in the form of triangular niches cut into the rock above the torch bearer's heads; lamps placed in these niches would sprinkle the Mithraeum with firelight, coming from the top of the torchbearer's head - the location proper to the stars of the Dioscuri. Ulansey proposes that the little-known account of the Dioscuri initiated into the rites at Eleusis would help naturalize their association with torches. 


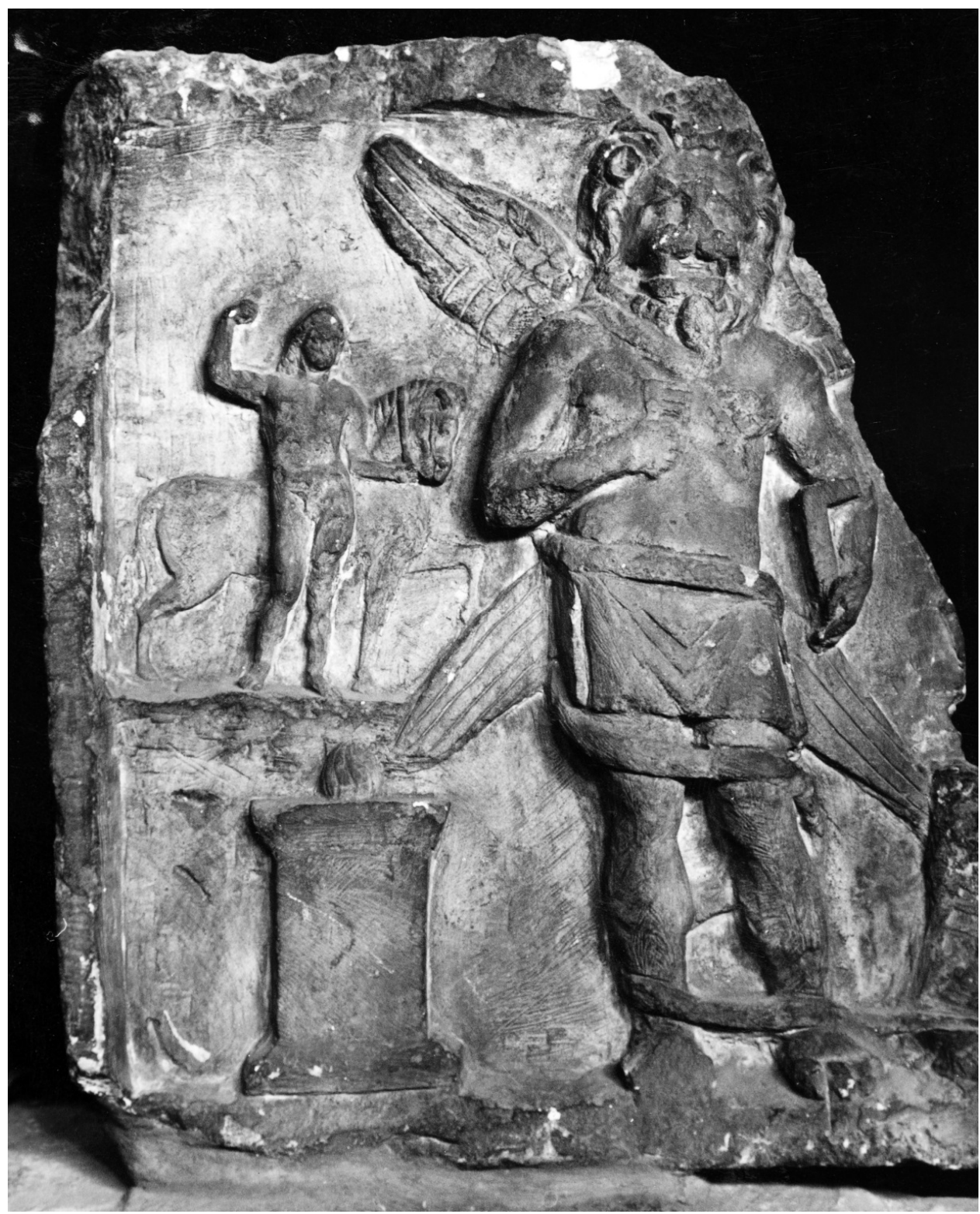

Fig. 5. Limestone low-relief, Vienne, France (CIMRM 902)

clutches the reins of his horse (fig. 5). The sum of these analogies leads Ulansey to the conclusion that the Dioscuri are the origins of the torchbearers.

This proposal reflects the well-established tendency to use comparative studies to identify lost origins. It also has substantial difficulties from scientific as well as iconographic perspectives. Swerdlow, as a historian of science, notes that the chrono- 
logical gap between the fourth millennium and Greco-Roman times is not well solved by Hipparchus, who admits his uncertainties about the precession. ${ }^{49}$ The iconographic comparanda are equally problematic. Hannah cautions that Ulansey is comparing data which originate in widely separated eras, from the 3rd and 2nd century BC Etruscan mirrors on which the Dioscuri stand with legs crossed to the philosophers of Imperial Rome. The parallels in crossed legs and pointed caps, moreover, are more impressionistic than precise. ${ }^{50}$ And Hinnell's compilation of the iconography of Cautes and Cautopates suggests the risks of constructing a history of origins based on attributes. Cautes has a bull's head in only seven monuments, far less often than he holds a pedum, cock or tree; he actually holds the scorpion in two representations. Cautopates, similarly, has a scorpion only four times, a significant minority of the preserved representations, and holds a bull's head a total of nine times. Those cases in which Cautes holds the sign of Taurus and Cautopates that of Scorpio uphold his argument elegantly, however, and indeed suggest the capacity for some users to conceptualize the pair as equinoxes. The case of Octavian Zeno and his family Mithraeum is a fine example of a privileged clan painting the portrait of their excellence in the colors of the god. From a historiographic perspective, extrapolation from these to a general principle or a broad historical account is ill advised. From the anthropological perspectives which Detienne seeks to reintroduce, however, Zeno's inscription is a model of the use of the flexible, polyphonic Mithraic vocabulary - a principle of selection and rearrangement, used to construct the communication most appropriate to its context and patron.

Beck foregrounds a deeper semantic coherence behind Ulansey's comparison between Dioscuri and torchbearers, by focusing on the metaphor of mobility in Mithraic contexts, and the funerary context of Dioscuri at Rome. The title 'Heliodromos' for one of the senior Mithraic grades suggests a role for motion in the cult experience; images help reconstruct its ritual experience. A cult vessel from Mainz depicts two cult members playing the roles of Cautes and Cautopates, holding rods rather than torches. They attend a cult member who may be identified as Heliodromos, as he carries a whip. The group suggests a ritual procession that enacted the cosmology of the rites, in which the sun runner moves along the 'pathway of the sun', conceptualized as its annual journey around the ecliptic. This trek defines and generates the seasons of the earth: the ritual actor marches out, in his performance, the calendrical sequences of the year. Cautes and Cautopates, corresponding to Porphyry's solstices, are present in the form of rod-bearers. ${ }^{51}$ Images on a vessel from Köln depict this sun running as carried out by the divine forces themselves rather than ritual actors, encouraging the notion of a divine play of the solar journey as one option within the

${ }^{49}$ Swerdlow (n. 6) 58-59; BeCK: In the Place (n. 13); SwERdLOw, N. M.: Hipparchus' Determination of the Length of the Tropical Year and the Rate of Precession. Archive for History of Exact Science 21 (1980) 291-309.

${ }^{50}$ HANNAH (n. 2) 184.

${ }^{51}$ BECK, R.: The Seat of Mithras at the Equinoxes: Porphyry De antro nympharum 24. JMS 1 (1976) 95-98; for caveats, see EZQUERRA (n. 9) 347-349. 
Mithraic cave. ${ }^{52}$ The cave emerges as the stage for the drama of the solar journey, on which the gap between participants and celestial bodies temporarily dissolves. The iconography of the tauroctony would support this experience, as its elements, read right to left, approximately match the sequence on the constellations west to east, e.g. the order in which they rise and set during the course of the year. ${ }^{53}$ Contemporary philosophical conversations suggest that these celestial routes signal the mortal experience of genesis and apogenesis.

The funerary context of the Dioscuri at Rome suggest an analogous articulation of movement, coupled with an association of the Dioscuri with light as a symbol of life. Cumont proposed three ways the Dioscuri came to function in the visual vocabulary of Roman death. ${ }^{54}$ The first transferred the twins' protection over seafarers to voyages through the ether, when the islands of the blessed were transposed to the stars. ${ }^{55}$ The second formed an analogy between the Dioscuri and the tomb's owner, as a sign the latter deserved apotheosis. The analogy was a familiar concept at Rome, with antecedents from Classical Athens to the Hellenistic court of Alexandria, where the twins were Arsinoe's choice as the vehicles for her heavenly ascent. ${ }^{56}$ The third arises from the Dioscuri's association with upper and lower hemispheres of the cosmos, as a paradigm of brotherly love. In philosophical contexts, this fraternal affection served as a symbol of the harmony of the universe. ${ }^{57}$ Stoics, for example, declared that the living organism of the world was united by a reciprocal sympathy, manifested in the movement of the spheres, the growth of vegetation, and all the phenomena of physical and moral life. This cosmic harmony takes iconographic form in either Erotes or Dioscuri. When the twins fulfill that function, their legendary affection forms a celestial analogue to the mortal love shared between husband and wife, as shown in a series of Roman sarcophagi on which the brothers frame the image of the deceased couple. Epitaphs suggest that the twins' ability to move between the realms of the living and the dead is also extended to husband and wife, whose souls have ascended to the sky. $^{58}$

${ }^{52}$ BECK: Ritual (n. 7) 159.

${ }^{53}$ BECK: Mithraism (n. 3) 2082.

${ }^{54}$ Cf. SzeligA, G. N.: The Dioskouroi on the Roof. PhD Thesis. Bryn Mawr College 1981, 171173; AsCHER, Y.: A Rediscovered Antonine Marble Horseman. AK 43 (2000) 102-109, here 107 and n. 34; LA ROCCA, E.: Memorie di Castore': principi come Dioscuri. In NISTA, L. (ed.): Castores - L'immagine dei Dioscuri a Roma. Rome 1994, 73-90.

${ }^{55}$ CUMONT: Recherches (n. 47) 64.

${ }^{56}$ Callimachus Diegesis of Aitia X 10; CUMONT: Recherches (n. 47) 67 n. 2; DEPEW, M.: Gender, Power, and Poetics in Callimachus' Book of Hymns. In HARDER, A. - REGTUIT, R. F. - WAKKER, G. C. (edd): Callimachus II [Hellenistica Groningana 7]. Leuven 2004, vol. 2, 117-138, here 130; SENS, A.: Theocritus: Dioscuri (Idyll 22): Introduction, Text and Commentary. Göttingen 1997, 23; FRASER, P. M.: Ptolemaic Alexandria. Vol. I. Oxford 1972, I 207.

${ }^{57}$ CUMONT: Recherches (n. 47) 86.

${ }^{58}$ CIL VI 13528 ... anima caelo reddita Bassa vatis, quae Laberi coniuga hoc alto sinu Frugeae matris quiescit, moribus priscis nurus. Animus sanctus cum marito'st, anima caelo reddita est. Parato hospitium: cara iungant corpora Haec rursum nostrae sed perpetuae nuptiae 
Stars and shining lights were part of that trek. The imagery appears on the coins of the Second Punic War, in the form of twin stars over the brothers who ride on galloping horses. Those stars are used only of the Dioscuri through the end of the second century, after which they appear as well above Roma, Mars, Mercury, Jupiter, Victory, Apollo and ultimately Venus, as a signal of Julius Caesar's apotheosis. ${ }^{59}$ Torches or sunlight underscore the imagery of death and resurrection: in the vault of a hypogeum on the Via Flaminia, stuccoes depict the Dioscuri, with lances and horses, accompanied by winged infants, one with torch up for Phosphoros, one with a torch down for Hesperos. ${ }^{60}$ On a sarcophagus from St. Laurent-hors-des-Murs, the Dioscuri are positioned next to rising Phoebus and setting Selene; a second sarcophagus from the site pairs them with sun and moon; a Vatican relief places them next to Tellus and Caelus.

These Roman funerary contexts suggest that both the Dioscuri and the torchbearers functioned as divine metaphors for the successful celestial journey of the human soul - one in the context of the cave, the other at the door of the tomb. The Mithraic experience closed the gap between the participant and the starry spheres, as the celebrants held torches, moved through space, and used their own bodies to walk through the cosmic map affirmed by the rites. The Dioscuri, as metaphors for the deceased, similarly dissolve the distinctions between an embodied mortal and a philosophical map of the heavens, enabled through an engaging myth of superlative affection. Both contexts reflect a proposal for re-generation and new life; both suggest the broad diffusion of the second level signifying power of twinned lights as an extension of the human form - held in the hand, twinkling above the head, or the pars pro toto signal of youths who journey between terrestrial and celestial realms.

\section{ROMANS ON SAMOTHRACE: CLAIMING THE RITES}

Samothrace provides another significant context for exploration of this comparison. It shares with Mithras the cultural category of a mystery initiation; it is distinct from Rome's 'oriental' mysteries in the cultural energies expended to claim the rites as genuinely Roman. These index the extent to which Romans found the Samothracian rites good for thinking about issues critical to Roman identity. Altars to the Samothracian Gods sat on the spina of the Circus Maximus; Roman writers claimed them as the origins of the Roman priesthood of the Salii, linked Etruscan kings and Roman

Hic corpus vatis Laberi, nam spiritus ivit

Illuc unde ortus : quaerite fontem animae.

Quod fueram non sum, sed rursum ero quod modo non sum;

Ortus et occasus vitaque morsque itid' est.

${ }^{59}$ Gurval, R. A.: Caesar's Comet: The Politics and Poetics of an Augustan Myth. MAAR 42 (1997) 39-71.

${ }^{60}$ CUMONT: Recherches (n. 47) 73-76. 
temples to the cult, and invented Samothracian origins for the Penates. ${ }^{61}$ Mythographers moved the Samothracian prince Dardanos to Italy, so Aeneas' theft of the Samothracian gods ultimately enables their homecoming. ${ }^{62}$ And the gods assumed the roles of cosmic entities - earth, sky, aether - as well as the Capitoline triad for Roman authors. ${ }^{63}$ These conceptions lie far beyond any Greek observations on the gods and their rites, so much so that it could see the Romans were making up a mystery out of whole cloth, with little more than a toponymic and geospatial referent to tie it to the original.

Romans are, however, the best-attested non-Greek participants in the rites themselves from the 2 nd century $\mathrm{BC}$ till the end of the 4 th $\mathrm{AD} .{ }^{64}$ Initiation was de rigeur for Romans living or traveling in Macedonia or the Greek East; historical texts and inscriptions on site suggest engagement that reached across the Roman social spectrum. Hundred and seventy-one inscriptions which list initiates have now been published from the island; 64 of these include or are dedicated by Roman initiates. While epigraphy may be an aristocratic habit, the experience of the rites was not, and the inscriptions show soldiers, households and boatloads of individuals who experienced the rites together. ${ }^{65}$ The earliest evidence for Roman dedications on the site suggest a shrewd awareness of the island's function as a billboard for power in the region. Marcellus, after his victory at Syracuse in 211, traveled all the way to Samothrace to consecrate part of his booty as thank offering to the gods (Plutarch, Marcellus 30.6). This extraordinary journey may be an appropriate thanks for a naval campaign, as the island's gods were famous for their maritime powers. It could also have been wise political calculus, a signal to the Macedonians who had, just four years earlier, struck an alliance with Hannibal. ${ }^{66}$ Less than fifty years later, Aemelius Paulus came to Samothrace to collect the defeated Perseus, who had fled to the island, presumably seeking asylum, after his defeat at Pydna in 168 BC. The envoy Lucius Atilius, in

${ }^{61}$ Circus Maximus: Varro Ant. I. fr. I = Probus in Vergili Bucolica 6. 31; Tertullian de Spectaculis 8. Salii: Critolaos FGH 823 F 1; Servius in Aeneidem 2. 235; Festus ed. Mueller, pp. 326, 329; ed. Lindsay, pp. 438-439; Plutarch Numa 13. 7; Servius in Aeneidem 8. 285. Kings: Macrobius Saturnalia 3. 4. 7-9 reports that Tarquinius Priscus was a Samothracian initiate, and built the Capitoline temple for the island's gods, see Kleywegt, A. J.: Varro über die Penaten und die 'Grossen Götter. Amsterdam 1972; Penates, see Lloyd, R. B.: Penatibus et Magnis Dis. AJP 77.1 (1956) 38-46; MASQUELIER, N.: Pénates et Dioscures. Latomus 25 (1966) 88-98; WissowA, G.: Die Überlieferungen über die römischen Penaten. Hermes 22.1 (1887) 29-57; Versnel, H. S.: Mercurius amongst the 'Magni Dei'. Mnemosyne 27.2 (1974) 144-151.

${ }^{62}$ Dion. Hal. Ant. Rom. 1. 68. 2-4.

${ }^{63}$ Varro LL 5. 10. 57-58; Augustine, de civ. Dei 7. 28; Probus in Vergili Bucolica 6. 31; Servius in Aeneidem 2. 296, 3. 264, 8. 679; Macrobius, Sat. 3. 4. 7-9.

${ }^{64}$ COLE, S. G.: The Mysteries of Samothrace during the Roman Period. ANRW 18.2 (1989) 15641598; WeSCOAT, B. D.: Insula Sacra: Samothrace between Troy and Rome. In GALl, M. (ed.): Roman Power and Greek Sanctuaries: Forms of Interaction and Communication. Athens 2013, 45-82.

${ }^{65}$ Dimitrova, N.: Theoroi and Initiates in Samothrace: the Epigraphical Evidence. Princeton 2008, no. 93, no. 49 p. 122-125, 194-195; SKARLATIDOU, E. K.: Katalogos myston kai epopton apo ti Samothraki. Horos 8-9 (1990-91) 153-172; CLINTON, K.: Epiphany in the Eleusinian Mysteries. ICS 29 (2004) 85-109.

${ }^{66}$ COLE (n. 64) 1570. 
a speech to the island's assembly, based his argument on the ritual requirements of the mysteries, arguing that the islanders had to surrender Perseus, since their rites forbade admission to murders. ${ }^{67}$ Familiarity with Samothracian realities also takes material form at Rome, from the second century BC onward. Architectural echoes of Samothracian monuments informed sacred architecture around the landscape of Rome, including the Porticus Octavia, the temple of Hercules Musarum, and the theater next to the Temple of Apollo in Circo, as well as the Temple of the Lares Permarini and the Round Temple on the Tiber. ${ }^{68}$ Romans would neither need to trek to the island, nor be initates themselves, to be familiar with the vocabulary of the rites - a familiarity which seems to have proven no impediment to inventiveness and adaptation.

\section{SHINING TWINS ON SAMOTHRACE: VARRO AND NIGIDIUS}

One of the few commonalities between Greek and Roman views of the rites is a role for the Dioscuri. The Roman evidence comes first from Varro and Nigidius Figulus, members of an elite circle of friends bound by philosophical interests and access to the top levels of political power in the late Republic. ${ }^{69}$ Their ideas had a long life, cited by Ampelius in the early 3rd century AD and Servius in the 4th-5th century AD. Neither Varro nor Nigidius restricted themselves to identifying a single divinity on the island: Varro also claimed that they included Earth and Sky, Jupiter, Juno and Minerva, and Nigidius that the Samothracian gods were Lares and Idaian Daktyloi. ${ }^{70}$ The role they suggest for the Dioscuri, however, is significant. Varro writes that most Romans of his time - ut volgus putat - believed that the two young men who stand before the doors at Samothrace were Castor and Pollux. ${ }^{71}$ While he claims this was an error, his report should be taken seriously. Attentiveness to physical evidence is a hallmark of his studies of religion: Augustine noted that Varro formed his impressions from many images on the site itself: multis indiciis collegisse in simulacris. ${ }^{72}$ Varro

${ }^{67}$ Livy 45. 5. 2-3, COLE (n. 64) 1571-1572; cf. LEVINE, D. S.: History, Metahistory, and Audience Response in Livy 45. CA 25.1 (2006) 73-108.

${ }^{68}$ POPKIN, M. L.: Samothracian Influences at Rome: Cultic and Architectural Exchange in the Second Century BCE. AJA 119.3 (2015) 343-373.

${ }^{69}$ RAwSON, E.: Intellectual Life in the Late Roman Republic. London 1985, 93-99; MusiAŁ, D.: «Sodalicium Nigidiani ». Les pythagoriciens à Rome à la fin de la République. Revue de l'histoire des religions 218.3 (2001) 339-367.

${ }^{70}$ Nigidius, Fr. 70 (SwobodA, A. P.: Nigidii Figuli Operum Reliquiae. Amsterdam 1964); Arnobius, Adversus nationes 3. 41.

${ }^{71}$ ut volgus putat: $L L$ 5. 10. 5-58. The doors in question have been identified as those of the Anaktoron, based on Hippolytus' description of two statues of naked men at that location - Hippolytus Refutatio omnium haeresium 5. 8. 9-10; CLINTON, K.: Stages of Initiation in the Eleusinian and Samothracian Mysteries. In Cosmopoulos, M. (ed.): Greek Mysteries: The Archaeology and Ritual of Ancient Greek Secret Cults. London 2003, 50-78 has brought into question their position before the doors.

${ }^{72}$ Augustine, de civ. Dei 7. 28; 4. 31; Varro Ant. I fr. 21; RüPKE, J.: Representation or Presence? Picturing the Divine in Ancient Rome. $A R G 12.2$ (2010) 181-196; CANCIK, H. - CANCIK-LINDEMAIER, 
was also exceptionally devoted to the rites: out of the fragments for his Divine Antiquities, five are dedicated to Samothrace, an extraordinary number in a work explicitly focused on Roman traditions. ${ }^{73}$ Explaining his zeal, Varro states that religion and philosophy share the task of preserving the great truths of the world soul. Early kings knew these and put them into forms which would be comprehensible to the philosophically educated, but should remain opaque to the masses. His dismissal of the opinion of the common Romans, when it came to understanding the images they identified as Dioscuri, is consistent with this belief.

Nigidius Figulus suggests an even more central role for the divine twins: he wrote that their catasterism was the topic of the mysteries themselves. Nigidius was considered second only to Varro in his intellectual reach. ${ }^{74}$ Ancient voices suggest that he may have viewed the rites through the neo-Pythagoreanism of the late Republic: Cicero deemed him the restorer of the Pythagorean sciences, and Jerome, many years later, described him as Pythagorus et magus (Chronicon p. 238). His observations on the Samothracian Dioscuri are preserved in the scholia to Germanicus' translation of Aratus' Phaenomenon of the 3rd century BC. ${ }^{75}$ As an astrologer, Nigidius would be a natural resource for the scholiast to have at hand to work through the Aratea. Cicero describes him in his Timaeus as a naturalist; his books include the astrological studies De ventis and Sphaera and a Latin translation of an Etruscan brontoscopic calendar. ${ }^{76}$ D'Anna argues for Pythagorean elements in the Sphaera: the choice of name indexes an eagerness to expose the meanings of the rota mundi and the harmony of the spheres, and hints at the Pythagorean conception of the perfect circle. ${ }^{77}$ The extant

H.: The Truth of Images: Cicero and Varro on Image Worship. In BARASCH, M. - ASSMANN, J. BAUMgaRTEN, A. I. (eds): Representation in Religion: Studies in Honor of Moshe Barasch. Leiden 2001, $43-61$.

${ }^{73}$ VAN Nuffelen, P.: Varro's Divine Antiquities: Roman Religion as an Image of Truth. $C P$ 105.2 (2010) 162-188; Varro, de re rustica 2. 1. 5; LL 7. 3. 34; 5. 10. 57-68; Ant. I fr. I; Ant. II 184.

${ }^{74}$ DICKEY, M.: Magic and Magicians in the Greco-Roman World. London 2003, 164-166; Aulus Gellius NA 119. 14. 1-3; Servius as Aeneidem 10. 175; MusiaŁ (n. 69); Della CASA, A.: Nigidio Figulo. Rome 1962.

${ }_{75}^{75}$ Della CASA (n. 74) 113-114, 120-121; These scholia are the most significant source for fragments of Nigidius' astrological works, the Sphaera, and correspond to the contents of the second chapter of the book of Ampelius, a treatise of the twelve zodiacal signs. They are the Scholia Basileensia and the Scholia Strozziana et Sanger-Manensia, and date to the 8th-9th centuries (BREYSIG, A.: Germanici Caesaris Aratea cum scholiis. Hildesheim1967; BAEHRENS, A.: Poetae Latini Minores. Vol. I. Leipzig 1879; GAIN, D. B.: The Aratus Ascribed to Germanicus Caesar. London 1976, 16-20 reviews the debate on whether the author was Germanicus or Tiberius. The poem fits Tiberius' interest as Suetonius (69.1) describes him, addicted to astrology and myth. For Germanicus as author, see LE BOEUFFLE, A.: Germanicus: Les Phénomenès d'Aratos. Paris 2003, viii-ix; PossAnZA, M.: Translating the Heavens: Aratus, Germanicus, and the Poetics of Latin Translation. New York 2004, 170-173.

${ }^{76}$ Cic. Timaeus 1.

${ }^{77}$ D'AnNA, N.: Publio Nigidio Figulo: Un pitagorico a Roma nel 1 secolo a.C. Milan 2008, 25 50, 61-64 and DELLA CASA (n. 74) 101-138 affirm the link between Nigidius and a Pythagorean circle at Rome, while TheslefF, H.: Rezension von Adriana Della Casa, Nigidio Figulo. Gnomon 37 (1965) 44 48 and Musiat (n. 69) caution that only one of Nigidius' fragments is genuinely Pythagorean in tone. CARCopino, J.: La basilique pythagoricienne de la Porte Majeure. Paris 1927, 196-202 connects him to the establishment of the Basilica at the Porta Maggiore as a 'Pythagorean chapel'. 
fragments suggest a concern to link the bodies and motions of the celestial world with the mythology of the classical, and thus reveal the spiritual roots from which those celestial rhythms emerged.

The context of Nigidius' preservation highlights the enthusiasm for 'oriental' astral religions in imperial Rome, and for the cultural usefulness of an astronomy more poetically engaging than scientifically accurate. ${ }^{78}$ Germanicus' translation of Aratus was but one of many: we know of at least six Latin translations of the work, three of which are extant, and 27 commentaries. ${ }^{79}$ Aratus was at the center of Greek literary culture: Cicero wrote that his exceptional success had nothing to do with astronomical accuracy but was a reflection of his exceptional eloquence. ${ }^{80}$ This eloquence earned a position for his text in the school curricula, where it remained through the Middle Ages. The astronomical topic responded to a range of cultural needs. It let Aratus and his Latin translators bring their poetic gifts to bear on a long line of Greek thinkers, from Hesiod through Hipparchus and Asklepiades. It responded to a quintessential Roman preoccupation with farmer and mariners, who relied on the practical knowledge of celestial signs. ${ }^{81}$ And when Ovid (Metam. 10. 148-149) uses the first line of the Phaenomena as the first line of Orpheus' cosmological didactic poem, we see a marriage of science and cultural imagination that anticipates Kuhn's observation of the relationship between astronomy and cosmology, and reflects the capacity of cosmology within the religious sphere, where it could grant the same veneer of chronological depth, Hellenistic refinement, and Roman cultural authority. ${ }^{82}$

Germanicus' scholiast writes:

Nigidius deos Samothracas dicit, quorum argumentum nefas sit enuntiare praeter eos qui mysteriis praesunt. Item dici Castorem et Pollucem Tyndaridas Geminorum honore decoratos, quod hi principes dicantur mare tutum $<a>$ praedonibus maleficiisque reddidisse. Et quo in tempore navigaverint cum Iasone atque Hercule ad pellem inauratam auferendam, multis laboribus tempestatibusque conflictati, periculorum atque nimborum experti impendio potius quam libentius, [navigantes laboribus liberare studuerunt] auxilium ferre precantibus instituerunt. Itaque cum ab Iove

${ }^{78}$ MeIER, M. - GÜNTHER, L.-M. - FANTUZZI, M. in Brill's New Pauly, Antiquity volumes. 2006, s.v. 'Aratus'. Consulted online on 08 April 2017 (http://dx.doi.org.proxy.library.emory.edu/10.1163/ 1574-9347_bnp_e131340); Le BOEUFFLE (n. 75) xxii; additional Phaenomena were composed by Alexander Aitoleus, Hermippus of Smyrna, Hegesianax of Alexandria, and Alexander of Ephesus.

${ }^{79}$ GEE, E.: Aratus and the Astronomical Tradition. Oxford 2013, 5-7; LE BOEUFfLE (n. 75) xi-xix.

${ }^{80}$ Cicero Rep. 1. 22; for others who priased his style, see Varro Menipp., Herc. Socr. 8, p. 146 Riese; Helvius Cinna, Fragm. Poet. Lat. Morel, p. 89, and esp. Ovid, Am. 1. 15. 16, Cum sole et luna semper Aratus erit: Quintilian Inst. 10. 1. 55 offers a more nuanced judgement. LE BOEUFFLE (n. 75) xix notes, in contrast, that Germanicus' goal seems to have been to update Aratus' out of date astronomy. In the passage to which Nigidius Figulus' F 70 is appended, Germanicus had little to correct in Aratus, though Hipparchus critiqued these lines.

${ }^{81}$ LE BOEUFFLE (n. 75) xvii.

${ }^{82}$ GEE (n. 79) 17. 
sunt elati, petiverunt a patre, sibi liceret in eo caelo constitui, unde mortalibus auxiliantes prospicere possent. ${ }^{83}$

Nigidius says that they (these stars) are the Samothracian gods, whose story may not be told by any except those who preside at the mysteries. The same Castor and Pollux, sons of Tyndaros, are honored as twins, because they are said to have been the first to rid the seas of pirates and evil doing. At the time they sailed with Jason and Hercules to get the golden fleece, when beset by many troubles and misfortunes, weathering perils and storms - more from necessity than from choice they became eager to free seafarers from troubles, they began to bring aid to those who prayed. Thus when they were raised up by Jove, they asked the father to let them remain in the sky, from which they could look down upon the mortals whom they aid.

Nigidius suggests that the tale of Castor and Pollux was told by those presiding at the Samothracian rites; the topic of the tale seems to be the catasterism of the young men, who were the first to rid the sea of pirates. The twins were more frequently catasterized because of the rape of the Leukippids, a story first preserved in Theocritus (22. 137) and re-told in the early Imperial period by Ovid (Fasti 5. 699) and Hyginus (Fab. 80) ${ }^{84}$ Germanicus was far more interested than Aratus in catasterisms: he more than doubled the number of such tales in his Aratea and, unlike his predecessor, infused the stories with the human emotion and high drama appropriate for mortals who earn a place in the heavens. ${ }^{85}$ Germanicus' embrace of these myths may reflect the service they rendered to the imperial family; indeed his proposal of maritime heroism, rather than a rape gone awry, enlists the Dioscuri's catasterism in euhemeristic traditions. ${ }^{86}$ Nigidius himself could have served as Germanicus' source for these Dioscuri, as he seems to have been for his accounts of Pisces and the constellation Hercules. ${ }^{87}$

The account, in its triangulation of the Dioscuri, Samothrace and maritime protection, suggests familiarity with the Argonautica in its Hellenistic forms. The Dioscuri

\footnotetext{
${ }^{83}$ For line 146 in Germanicus' Aratea: Qua media est Helice, subiectum respice cancrum; / at capiti suberunt gemini. Germanicus relates the tale of their katasterism elsewhere, at lines 540-542.

${ }^{84}$ Cf. CAlzASCIA, S. C.: Deifications and Catasterisms in Ovid's Fasti. Giornale Italiano di Filologia 66 (2014) 139-162; DICKS, D. R.: Astrology and Astronomy in Horace. Hermes 91.1 (1963) 60-73; KIDD, D. A.: Astrology for Maecenas. Antichthon 16 (1982) 88-96; BAKHOUCHE, B.: L'astrologie à Rome [Bibliothèque d'Études classiques 29]. Louvain-Paris 2002; PENDERGRAFT, M.: Aratean echoes in Theocritus. QUCC 24.3 (1986) 47-54.

${ }^{85}$ POSSANZA (n. 75) 170-173.

${ }^{86}$ FOX, M.: Stars in the Fasti: Ideler (1825) and Ovid's Astronomy Revisited. AJP 125.1 (2004) 91-133; GreEN, P.: Getting to be a Star: The Politics of Catasterism. In GREEN P. (ed.): From Ikaria to the Stars: Classical Mythification, Ancient and Modern. Austin 2004, 234-249; MATTHEWS, V. J.: From 'Coma' to Constellation: Callimachus, Catullus, and Catasterism. Eranos 102 (2004) 47-57; PELLACANI, D.: The Catasterism of Eridanus: Aratus and His Latin Translations. Studi italiani di filología classica 12.1 (2014) 106-125.

${ }^{87}$ LE BOEUFFLE (n. 75) 283.
} 
are associated with the narrative already in the 6th century $\mathrm{BC}$, when they appear alongside the Argo on the metopes of the Sicyonian treasury at Delphi. ${ }^{88}$ Their aid to mariners has similarly archaic roots: Alkaios provides a dramatic account of the journey of the twins from the Peloponnese to a ship in distress, and their heroic leap up to the mast to provide light for the beleaguered travelers. ${ }^{89}$ Xenophanes in the 6th century and Metrodoros in the 4th describe their manifestation as St. Elmo's fire, the electrical phenomenon that plays about the masts of ships. ${ }^{90}$ The journey and the maritime powers are brought to the island, however, only in the Hellenistic, when the Argonautica provides a narrative framework for adding the Dioscuri's maritime powers to the long list of ritual means through which the island articulated safety over travel at sea. ${ }^{91}$ Those promises were well known at Rome. The late Republican temple to the Lares Permarini has been interpreted as a recognition of the maritime power of the island's rites; M. Aemilius Lepidus' vowed its construction when he engaged in a sea battle against the king of Antioch. ${ }^{92}$ While Zevi has noted the brevity of the cult of the Lares Permarini, the desire for divine aid at sea informs the imperial authors Ovid (Fasti 5. 20, Tristia 1. 10. 45-50), Seneca (Naturales questiones 1. 1. 13), Horace (c. 1. 12. 27-28; c. 4. 8. 31-32), Hyginus (Astron. 2. 22) Aelian de Natura animalium 15. 23, fr. 90; Athenaeus Deipnosophistae 7. 283a. ${ }^{93}$ St. Paul describes ships were decorated with their images; at the end of the 5th century $\mathrm{AD}$, their ritual honors were re-instated at Ostia (Gelasius tract. 68).

\section{VISUAL EVIDENCE: INSCRIPTIONS}

To these widely familiar uses of the twins, Nigidius adds a remarkable claim: the Dioscuri's catasterism was the narrative of the mystic rites. Hints regarding the stories told in the rites is not unparalleled: Ephoros, as cited by scholiast to Euripides'

${ }^{88}$ Szeliga, G. N.: The Composition of the Argo Metopes from the Monopteros at Delphi. AJA 90.3 (1986) 297-305.

${ }^{89}$ PAGE, D. L.: Sappho and Alcaeus. Oxford 1983, 265, B2(a).

${ }^{90}$ Xenophanes, Diehls VS 21 A 39; Metrodoros, VS 70 A 10; see also Homeric Hymn 33, Alcman Fr. 34, Euripides, Helen 1495-1505, 1664-1665; JAISLE, K.: Die Dioskuren als Retter zur See bei Grichen und Römern und ihr Forteben in christlichen Legenden. Dissertation, Tübingen 1907, 58-72. LORENZ, T.: Die Eiphanie der Dioskuren. In Froning, H. - HölSCHER, T. - MielsCH, H. (eds): Kotinos: Festschrift für Erika Simon. Mainz am Rhein 1992, 114-122. Diodorus Siculus suggests that they acquired this divine power in the course of the voyage itself: 4. 43. 1-2. SKUTSCH, O.: Helen, Her Name and Nature. JHS 107 (1987) 188-193; LUNDQUIST, S.: On the Discharge of Static Electricity: Some Historic Notes with Comments and Remarks. Journal of Electrostatics 16.2-3 (1985) 221-230; WHITE, H.: Notes on the Text of Euripides. Myrtia 15 (2000) 51-67.

${ }^{91}$ BLAKELY, S.: Beyond Braudel: Network Models and a Samothracian Seascape. In L. MAZUREK Concannon, C. (edd): Across the Corrupting Sea. London 2016; Scherer, B.: Mythos, Katalog und Prophezeiung: Studien zu den Argonautika des Apollonios Rhodios. Stuttgart 2006, 9-42 for all the ancient sources.

${ }_{92}$ Livy 40. 52. 4-7. The temple appears in the Fasti Praenestini, but then disappears until a brief mention in Macrobius Saturnalia 1. 10. 10; see POPKIN (n. 68) 347-351.

${ }^{93}$ ZEVI, F.: Il tempio dei Lari Permarini. MDAI(R) 104 (1997) 81-115. 
Phoenissae 7, suggests that even in his day the Samothracians search for Electra in their festivals. ${ }^{94}$ Nigidius' proposal finds exceptional correlation in an inscription from Kavala, which suggests an encounter with those shining lights at the heart of the Samothracian experience. The inscription is an epitaph for an Athenian initiate of the 2 nd-1st centuries BC, Isidorus son of Nikostratos. ${ }^{95}$ Isidorus was an actor, possibly the mime Cicero mentions in his speech against Verres. ${ }^{96}$ He had been an initiate at Eleusis as well as Samothrace: of these initiations we read (lines 13-16):

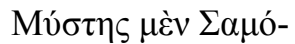

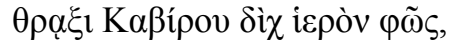

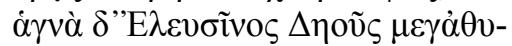

$$
\begin{aligned}
& {[\mu \mathrm{o}] \varsigma \mathrm{i} \delta \varepsilon \varepsilon v \text {. }}
\end{aligned}
$$

As an initiate, great-hearted

He saw the doubly sacred light

Of Kabiros in Samothrace

And the pure rites of Demeter in Eleusis

The term $\varphi \tilde{\omega} \varsigma$ may be used with a genitive to indicate the light of torches, moonlight or starlight: the 'light of the sun' is a metaphor for being alive. ${ }^{97}$ The syntax of this inscription specifies the Kabeiroi as the source of the shining light. The Kabeiroi were one of five different types of daimones associated with the Samothracian rites, who share significant categorical overlap through some 1000 years of literary attestation. The Kabeiroi's functions range from the sons of Hephaistos to the divine patrons of Lemnian mysteries. ${ }^{98}$ Their specification as a duality - 'Sì' ' here most suggests the Kabeiroi as doublets for the Dioscuri in their manifestation as stars. This was a well-known equation, mentioned in literary sources from fifth century Athens through late-antique Orphic hymns and the Neoplatonists of the 6th century AD. ${ }^{99}$ Polemon of Ilium, a 2nd century BC periegetic writer famously attentive to inscriptions, wrote that one appearance of the twin stars that appear to those imperilled at sea is that of the Dioscuri, the other that of the Kabeiroi. ${ }^{100}$ Textual and material evidence for the

${ }^{94}$ FGH 70 F 120. cf. LeHMANN, K.: Samothrace: Fifth Preliminary Report. Hesperia 21.1 (1952) 19-43, here 30 n. 41; CLINTON: Stages (n. 71).

${ }^{95}$ Dimitrova (n. 65) no. 29, p. 83-90; KARADima, C. - Dimitrova, N.: An Epitaph for an Initiate at Samothrace and Eleusis. Chiron 33 (2003) 335-345.

${ }^{96}$ In Verrem 2. 3. 34; 2. 5. 12. 31;2. 5. 31.81.

${ }_{97}^{97}$ LSJ póos.

${ }^{98}$ Blakely, S.: Myth, Ritual and Metallurgy in Ancient Greece and Recent Africa. New York 2006, 17-53.

${ }^{99}$ They are also said to be the same as Korybantes and Kouretes. HemBERg, B.: Die Kabiren. Uppsala 1950, 215-216, 330, 334-335; CHAPOUTHIER (n. 37) 181-183; Aristophanes, Pax 276-287; cf. Euripides, Orestes 1635-1637; Pausanias 10. 38. 7; Philo in Eusebius, Praeparatio evangelica 1. 10 (FHG III 567); Damascius, Vita Isidori 302; Polemon FHG II 137, fr. 76 a, Scholia to Euripides Orestes 1637; Orphic Hymn 38; Ampelius, Liber memorialis 2. 3, Scholia to Germanicus Caesar Aratea 146, Varro, $L L$ 5. 10. 57-58).

${ }^{100}$ FHG III 137, Scholia to Euripides Orestes 1637, Polemon F 76a. Athenaeus (6. 234D) notes that Polemon was called 'stelokopas', 'stele glutton'. 
experience of the rites suggest a range of ways in which the initiates encountered twin lights on Samothrace.

Nonnos confirms a role for torchlight in the island's rites in his sprawling late fourth century epic of Dionysos: he describes the sailors' joy at seeing the 'sleepless flame of the Samothracian torch' (3. 43-44), the nocturnal festivities of the island (4. 185), and the statues which hold blazing torches before the banqueters (3. 169171). ${ }^{101}$ Such torches would have been small enough to hold in the hand: the statues Nonnos references could be imagined as analogues to the torch-bearing figures in the Eleusinian mysteries. At Eleusis, the torches so carried were part of the initiate's replication of the experience of Demeter, who roamed the world using torches to search for her daughter. ${ }^{102}$ Much smaller, but similarly capable of being borne in the hands of initiates, are the multiple lamps found in the so-called sacristy attached to Samothrace's Anaktoron. ${ }^{103}$ Dimitrova has noted that these could become the lights of the twofold Kabeiroi when they were used to illuminate the twin-like statues which Hippolytus described standing before the doors of the Anaktoron (site plan [fig. 6] no. 23):

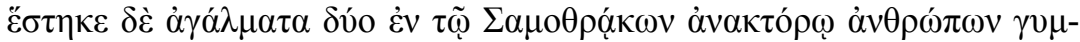

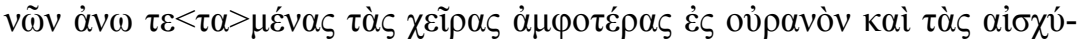

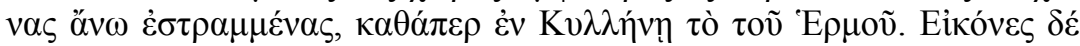

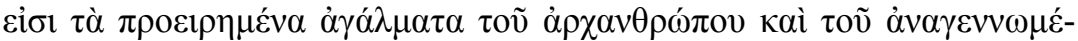

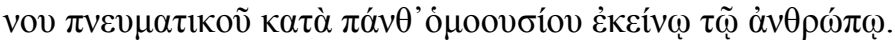

In the Anaktoron of the Samothracians there stand two statues of naked men with both their hands stretched up toward heaven and their pudenda turned up, just as in the statue of Hermes on Kyllene. The aforesaid statues are images of the primal man and of the regenerative spirit in every respect consubstantial with that man (Refutatio omnium haeresium 5. 8. 9-10).

Four Samothracian inscriptions from the second and first centuries BC suggest less mobile glowing lights positioned around a door, in non-anthropomorphic form; three of these preserve Roman as well as Greek names. The first was seen and drawn by Cyriacus of Ancona in 1444: it records initiates and hieropoioi from Cyzicus ${ }^{104}$ (fig. 7). The upper portion of the stone as well as Cyriacus' original drawing have been lost, but three manuscripts preserve Cyriacus' sketch, and fragments of the stone

${ }^{101}$ Cf. Dimitrova (n. 65) 2008: 88; Cole, S. G.: Theoi Megaloi: The Cult of the Great Gods at Samothrace. Leiden 1984, 36-37.

${ }^{102}$ Clinton: Epiphany (n. 65); EdwARDS, CH. M.: The Running Maiden from Eleusis and the Early Classical Image of Hekate. AJA 90.3 (1986) 307-318; ClinTON: Stages (n. 71); PETRIDOU, G.: "Blessed Is He, Who Has Seen": The Power of Ritual Viewing and Ritual Framing in Eleusis. Helios 40.1 (2013) 309-341.

${ }^{103}$ LeHMANN, K.: Samothrace: Third Preliminary Report. Hesperia 19.1 (1950) 1-20.

${ }^{104}$ Dimitrova (n. 65) no. 58, pp. 140-44, IG XII 8. 190-192; LeHMANN-HARTLEBEN, K.: Cyriacus of Ancona, Aristotle, and Teiresias in Samothrace. Hesperia 12.2 (1943) 115-134, here 117-122; Chapouthier (n. 37) 176; Lehmann, P. W.: Cyriacus of Ancona's Visit to Samothrace. In LEHMANN, P. W. - LeHMANN, K. (edd): Samothracian Reflections: Aspects of the Revival of the Antique. Princeton $1973,3-56$. 


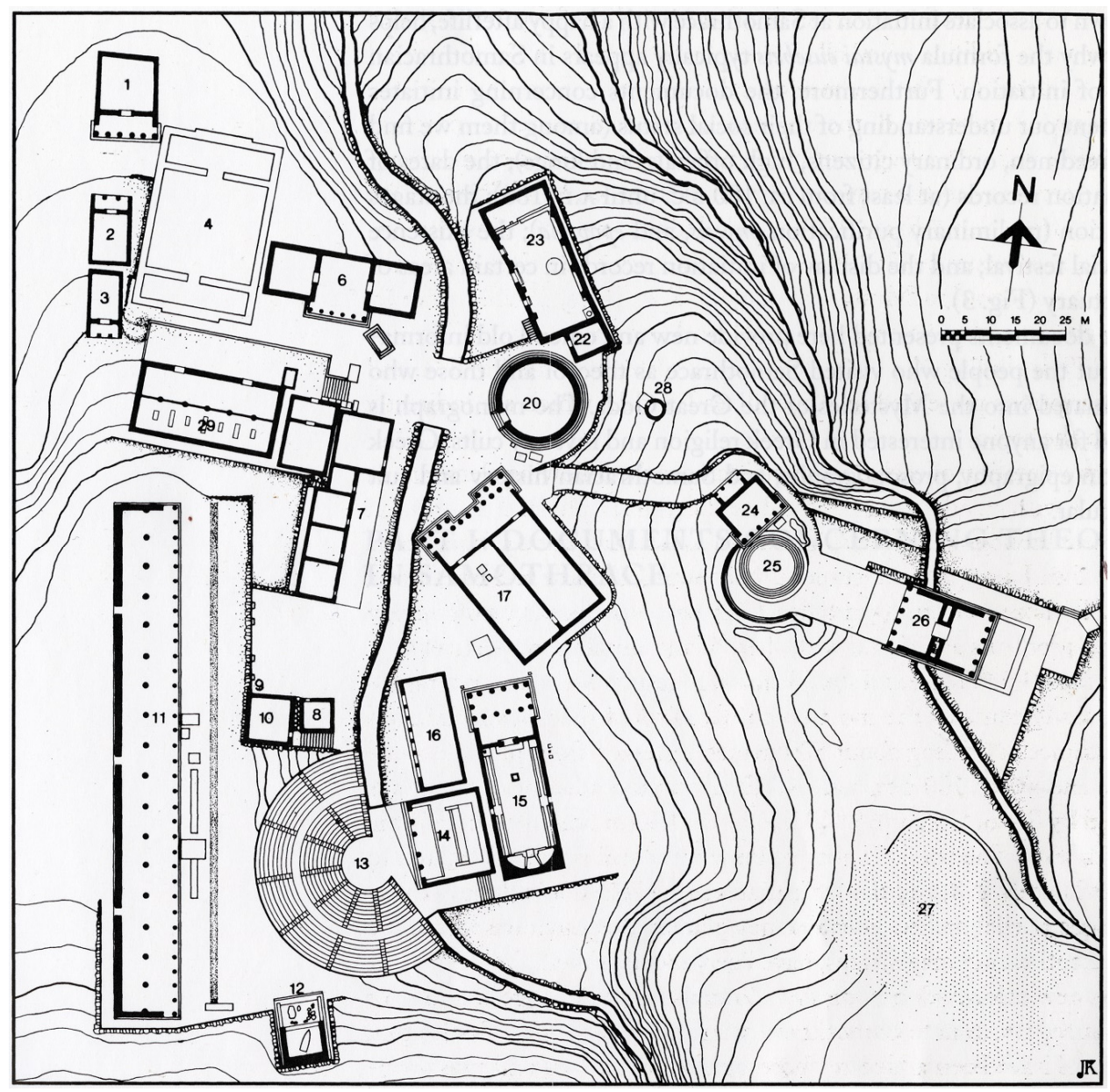

Fig. 6. Plan of the Samothracian sanctuary (Dimitrova [n. 65] 5 fig. 3)

discovered in the 20th century have helped confirm the accuracy of his record. The initiate's names are engraved around a drawing of monumental doorway, framed by two flaming upright torches, around which snakes crawl upward; the flames intersect with a line of garland and bucrania which top the building. On the roof stand three figures, one on a chariot drawn at great speed by four horses, the other two standing on either side of the scene. The names on the stone are mostly Greek, but include M. Oppius Neros and Q. Visellius L., alongside the list of initiates and hieropoioi from Cyzicus. ${ }^{105}$ A second inscription, dated to the 2 nd -1 st centuries BC, records Roman

${ }^{105}$ The Visellii of Brundisium are known in the first century BC as wine growers and exporters; this person could also be connected to L. Visellius Varro, consul in AD 24. See CIL X 545. FRASER, P. M.: Samothrace: The Inscriptions on Stone. Vol. 2.1. New York 1960, 30. 


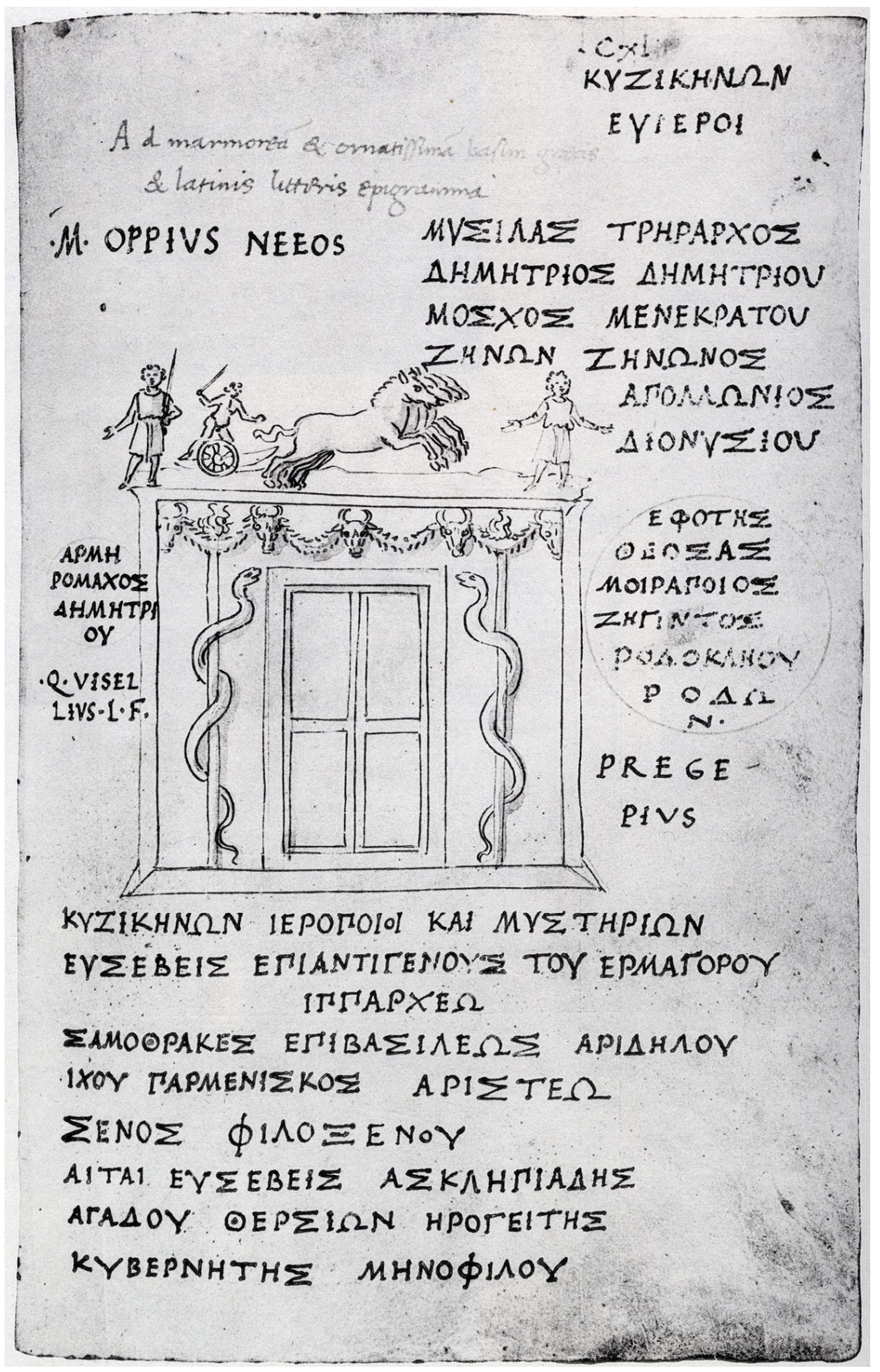

Fig. 7. Copy of Cyriacus' sketch (FrASER [n. 118] pl. XIV 29) 

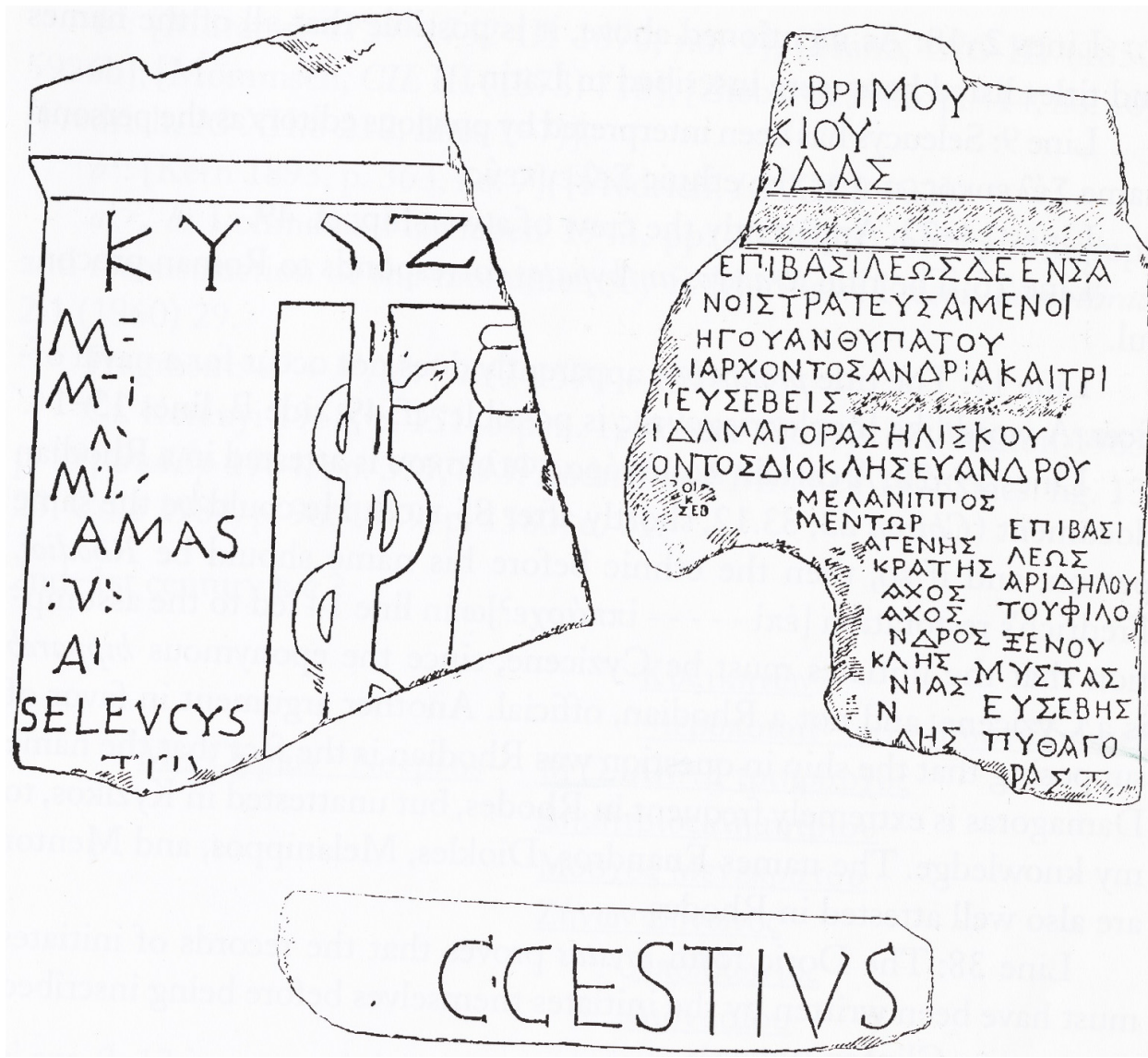

Fig. 8. Records of Roman initiates of unknown provenance, and of initiates from Maroneia, Rhodes (?), and Cyzicus (DimitRova [n. 65] 139, fig. 45)

initiates alongside initiates from Maroneia, Cyzicus and possibly Rhodes; a relief on the front depicts a round building framed by torches, around which wind the forms of snakes $^{106}$ (fig. 8). Side A records one Roman name alongside Greek initiates; side B includes initiates of a naval crew, possibly from Rhodes, and a single Roman name, C. Cestius, written vertically. A C. Cestius, consul in AD 35, is known from other records, but may or may not be the person listed here. A third, also dated to the 2nd1 st century BC, is now in Bignor Park, Sussex; its upper portion preserves a round building, flanking torches wound with snakes, and a pediment with traces of a circular object ${ }^{107}$ (fig. 9). Fauvel described a figure he identified as Kybele beneath the

${ }^{106} I G$ XII 8. 189; DimitrovA (n. 65) no. 57, pp. 137-139, with image.

${ }^{107}$ WinbolT, S. E.: Ancient Sculptured Marbles at Bignor Park, Sussex. JHS 48.2 (1928) 178182; Dimitrova (n. 65) no. 56, pp. 135-137, IG XII 8. 188. 


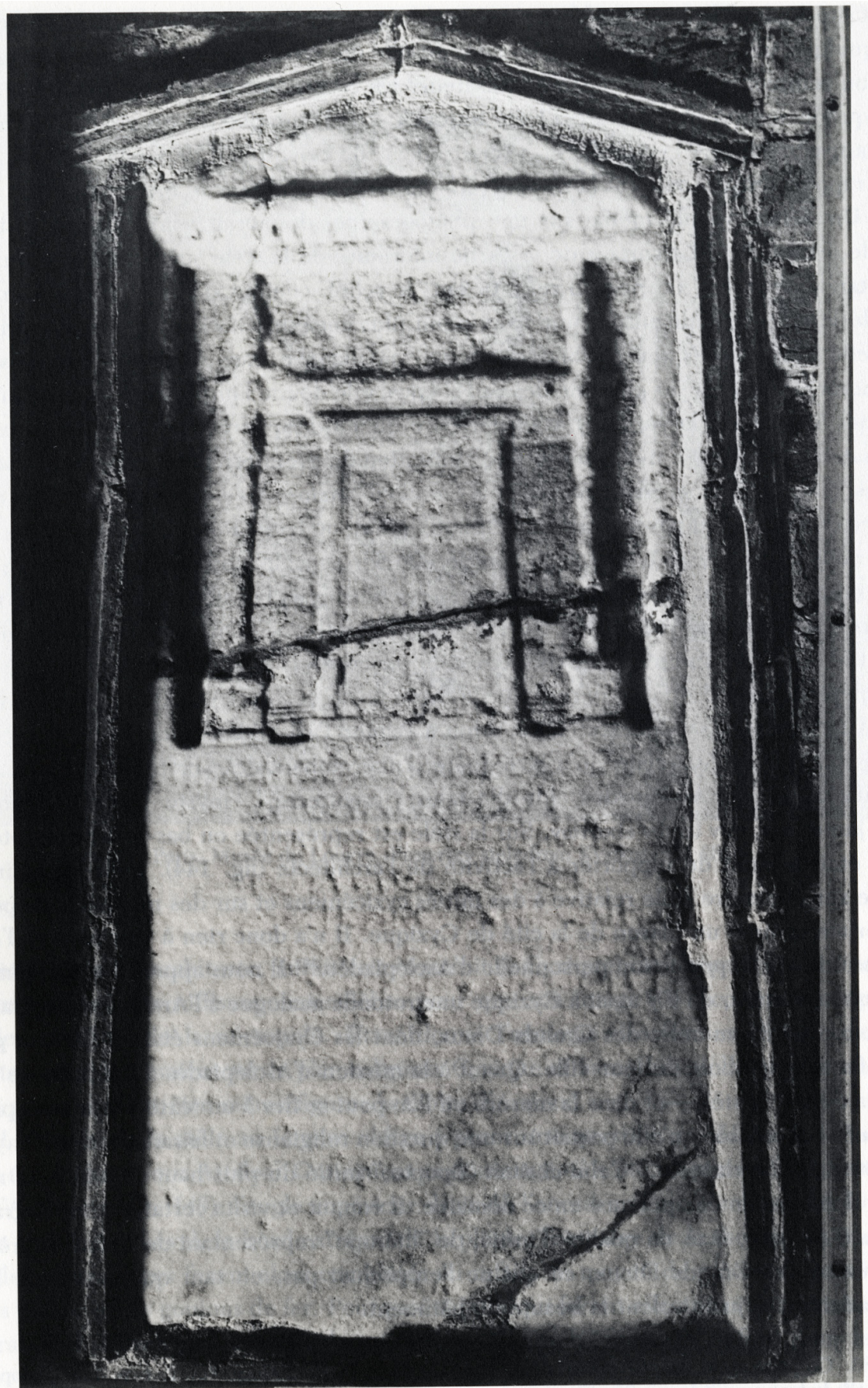

Fig. 9. Bignor park inscription (MCCREDIE, J. ET AL.: Samothrace 7: The Rotunda of Arsinoe, Princeton 1992, 226, fig. 144) 


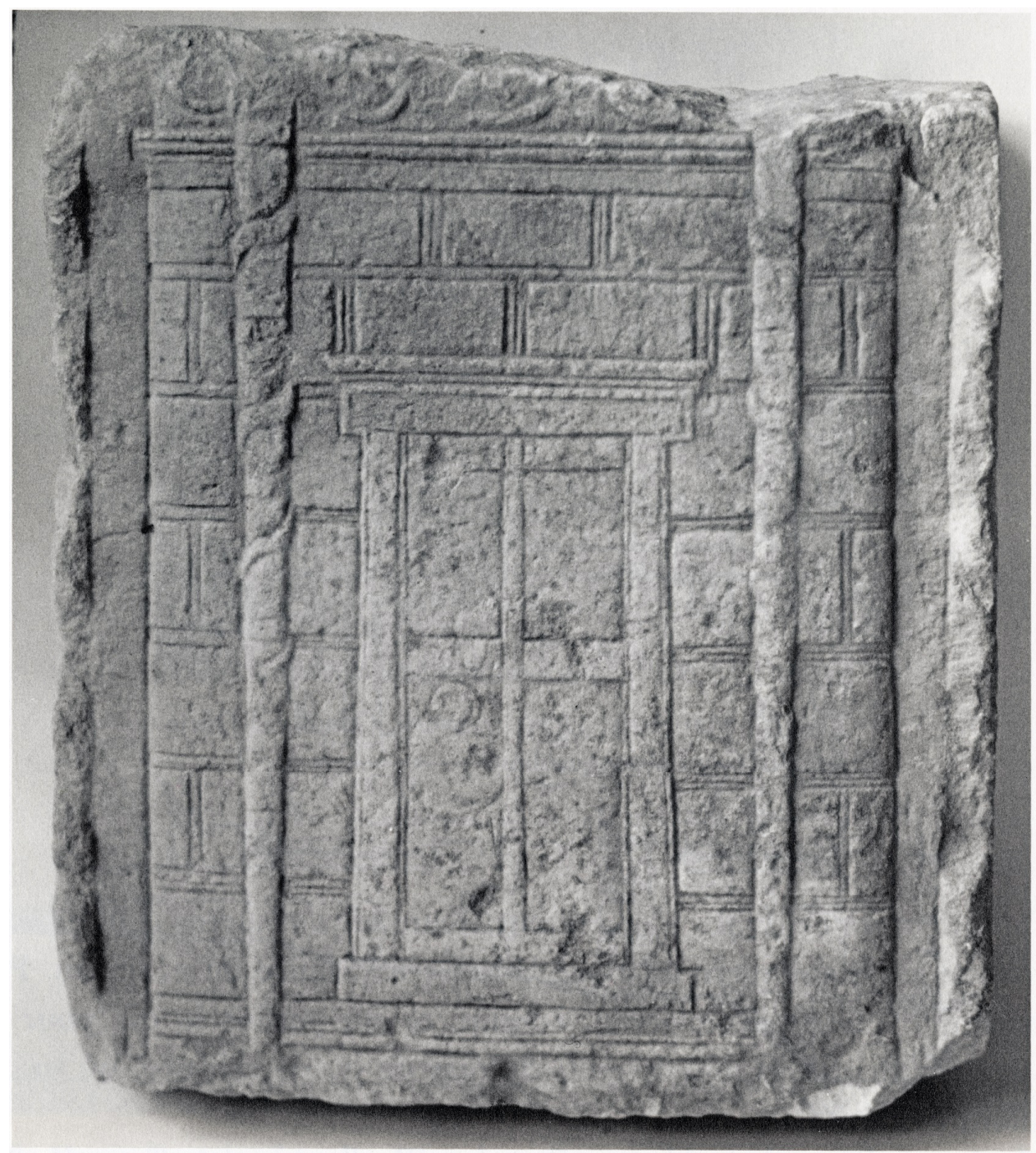

Fig. 10. Samothrace Museum, Hall B. Fragmentary inscribed stele 68.55 (MCCREDIE, J. ET AL.: Samothrace 7: The Rotunda of Arsinoe, Princeton 1992, 116, fig. 79)

pediment in a rectangular area. A fourth, dated to the 1st century BC, shows Roman initiates from an unknown provenance, and initiates from Alopekonnesos and Tralles - the front of the Thasian marble stele depicts a round building with a door, flanked by snake-entwined torches on both sides ${ }^{108}$ (fig. 10).

${ }^{108}$ Dimitrova (n. 65) no. 47, p. 119; IG XII 8. 190. 
The presence of a decorative motif sets these inscriptions apart among the Samothracian initiate lists, which are generally void of decoration. Three of the four inscriptions mention people sent to the sanctuary on a sacred mission, functioning as hieropoios, hieragogos, or katangeleus. Dimitrova proposes that this offers one explanation for the image used: as the doorways are understood to be part of a round building, these special messengers may have enjoyed a festive dinner in the Rotunda of Arsinoe as part of their Samothracian experience. ${ }^{109}$ The relative rarity of the image would correspond to the relatively small numbers of individuals with these titles in the inscriptions.

The meaning of the scene on top of the building has been debated. Lehmann proposed they represent the Samothracian tale of Zeus attacking Iasion with a thunderbolt, while Dardanos, Iasion's brother observes from the left. ${ }^{110}$ Rubensohn, critiquing Cyriacus' depiction of the drapery, proposed that the central figure was female, and that the scene represents the rape of Harmonia. ${ }^{111}$ Phyllis Lehmann notes that bronze coins from Cyzicus of the 2 nd and 3 rd centuries AD depict a round building, flanked by snake-wound torches which stand separate from the building rather than built into it. ${ }^{12}$ On its roof stand figures which are more clearly discernible than those as preserved on any of the reliefs. These are three females, a central figure who raises a torch in each hand, flanked by two similarly draped figures. One coin struck under Gallienus depicts a central figure standing in a chariot, with direct analogy to the image of the stele as preserved in the Ambrosian drawing of Cyriacus' sketch $^{113}$ (fig. 11). Phyllis Lehmann and Chapouthier identify the central figure with Cybele, who received cult attention in both Cyzicus and Samothrace, flanked by her male attendants, which should be understood as Dioscuri, Kouretes, or Korybantes. ${ }^{114}$ All three copies of Cyriacus' lost drawing show these two lateral figures as beardless males in short chitons, which was the modality for depicting the twins on the imperial coinage of Pisidia. ${ }^{115}$ A location on the rooftop for the Dioscuri is familiar from their celebrations both on the Greek mainland and in Southern Italy and Sicily; both Robertson and Szeliga have proposed a specifically maritime role for the heroes when positioned on the roofs, consistent with appeals made to the Dioscuri by sailors in distress on the high seas. ${ }^{116}$ Such an association would further naturalize the choice of position for these figures on the Samothracian reliefs.

${ }^{109}$ Dimitrova (n. 65) 137.

${ }^{110}$ LEHMANN-HARTLEBEN (n. 104) 121-122.

${ }^{111}$ RuBENSOHN, O.: Mysterienheiligtümer in Eleusis und Samothrake. Bonn 1892, 181.

${ }^{112}$ LEHMANN: Cyriacus (n. 104) 32 and fig. 24; 36 and n. 69.

${ }^{113}$ Coin, LeHMANN: Cyriacus (n. 104) 37 and fig. 26b; Ambrosian drawing, LeHMANN: Cyriacus (n. 104) 28 and fig. 20, after Cyriacus, Ms. A55 inf, fol. 69v, Milan, Biblioteca Ambrosiana.

${ }^{114}$ LeHMANN: Cyriacus (n. 104) 38; CHAPOUTHIER (n. 37) 176-180; this also confirms Fauvel's claim to have detected Kybele in the field above the building now in Bignor park: LEHMANN, K.: Chapter IV: The Epopteia and the Function of the Hieron. In LeHMANN P. W. ET AL.: Samothrace. Vol. 3: The Hieron. Part 2: Text II. Princeton 1969, 3-50, here 47.

${ }^{115}$ ChAPOUTHIER (n. 37) 58.

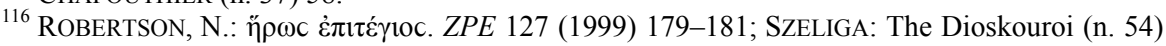
171-175; AsCHER (n. 54); GUZzO, P. G.: I Dioscuri in Magna Grecia. In NisTA, L. (ed.): Castores - L'immagine dei Dioscuria. Rome 1994, 27-32, fig. 3. 


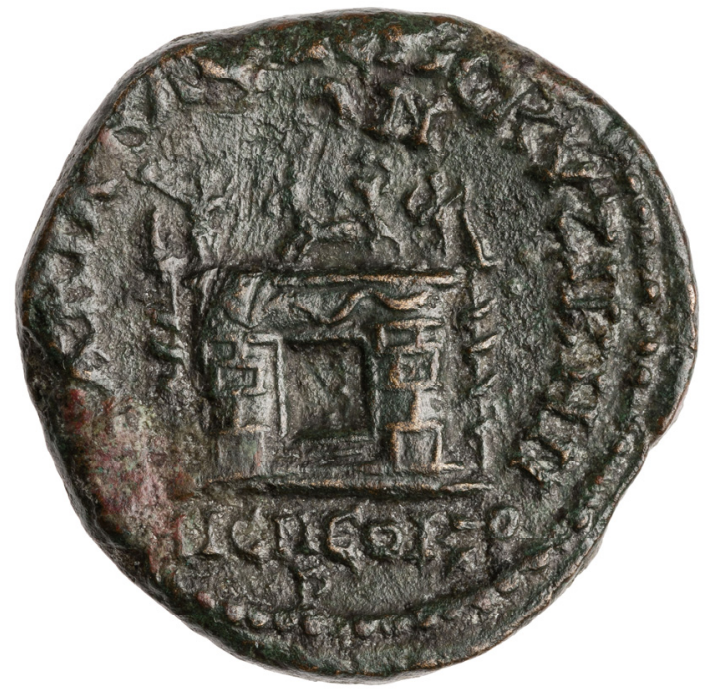

Fig. 11. Cyzicene coin of Gallienus, American Numismatic Society Acc. no. 20.

Courtesy of the American Numismatic Society

Phyllis Lehmann used Cyzicene coins to argue for an association between these inscriptions and the Arsinoeion (site plan [fig. 6] no. 23). As the largest round structure at the site, it has long been identified as the round building to which the doors gave entrance. ${ }^{117}$ As the monumentalization of Arsinoe's relationship to the island and its rites, it would be a deeply appropriate location for signaling the Dioscuri's attendance on a divine alpha female. Arsinoe's devotion to the Samothracian cult has been linked to the asylum on the island granted her: she fled there from the murderous intentions of Ptolemy Keraunos after the death of her husband Lysimachos, who shared with his royal line a history of generosity to the island's gods. A fourth century inscription records altars and annual sacrifices established for him on the island, in commemoration of his piety which brought to justice the scoundrels who attacked the sanctuary. ${ }^{118}$ A second decree praises his actions in connection with the island's hiera chora ${ }^{119}$ Samothrace's maritime powers also reinforced Arsinoe's own assumption of power over the sea. She was celebrated as Euploia and Zephyrite, and seems, in Posidippus' epigrams, to be fully assimilated to Aphrodite as a maritime protectress. ${ }^{120}$ The Dioscuri were central in this deification. Arsinoe seems to have intro-

\footnotetext{
${ }^{117}$ RUBENSOHN (n. 111) 158-64; Dimitrova (n. 65) 135-144; LEHMANN (n. 104); LEHMANNHARTLEBEN (n. 104) 118, n. 17.

${ }^{118} I G$ XII.8 150, FRASER (n. 105) 13.

${ }^{119}$ MCCREDIE, J. R.: Samothrace: Preliminary Report on the Campaigns of 1965-1967. Hesperia 37.2 (1968) 200-234, here 220, inv. no. 65.843; 323-316 BC: COLE: Theoi (n. 101) n. 130.

${ }^{120}$ BING, P.: Posidippus and the Admiral. GRBS 43 (2002-2003) 243-266, here 257; DEMET-

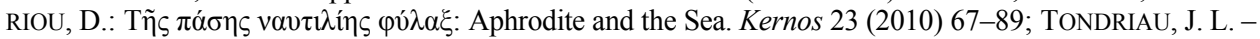
Tondriau, J. E.: 'Notes Ptolémaïques. Aegyptus 28.1-2 (1948) 168-177; BARBANTANI, S.: Goddess of
} 
duced their cult into Alexandria; their cult played a key role in the Ptolemaic court, as a divine model of fraternal affection apt for the Theoi Adelphoi. Callimachus commemorates Arsinoe's choice of the twins as her vehicles for her apotheosis. An interpretation of these figures as Dioscuri attendant on Cybele in the context of the Arsinoeion would represent one more confirmation of Arsinoe's deployment of the cultural vocabulary assimilating Ptolemaic queens to divine alpha females. ${ }^{121}$

\section{ARCHITECTURAL EXPERIENCE: TORCHES AT THE DOOR}

These exceptional inscriptions thus suggest an iconography for the Dioscuri on Samothrace - and one in which flaming torches, positioned around monumental doors, were a consistent element. Architectural evidence for these images comes, however, not from the monument of Arsinoe, but the Hieron. The Hieron, a large, enclosed, rectilinear structure, was completed in the second century BC (site plan [fig. 6] no. 15). Its interior was fitted with bleacher-like seats to enable full view of the actions carried out inside: these could support 144 people, possibly witnesses to those undergoing epopteia. ${ }^{122}$ Roman investment in this space is suggested by renovations carried out in the island's Roman era: these included ornate benches for the section nearest the building's apse. Among the things to be seen would have been flames which emerged from the earth itself, in the form of two escharai built into the marble floor. The Hieron terminated in a semi-circular apse - ordinarily a place for the cult statue, but in this building the home instead for a semi-circular hole cut in the floor. The floor which preserves this cutting also dates to the Roman period repairs to the building. The Austrian excavators termed this structure a bothros, as it seems designed to grant access to the bedrock beneath, from which protruded a large piece of red porphyry. ${ }^{123}$

The exterior of the building gives no hint as to the existence of the apse, as it is perfectly rectilinear. That exterior illusion was reinforced inside the building by the use of a curtain, suspended between two snake-wound torches, which hid the view of the rounded interior wall from those assembled inside ${ }^{124}$ (fig. 12). The torches which

Love and Mistress of the Sea: Notes on a Hellenistic Hymn to Arsinoe-Aphrodite. Ancient Society 35 (2005) 135-165.

${ }^{121}$ Callimachus Diegesis of Aitia X 10: CUMONT: Recherches (n. 47) 67 and n. 2; DEPEW (n. 56) 130; SENS (n. 56) 23; FRASER: Ptolemaic Alexandria (n. 56) I 207.

${ }_{122}$ LEHMANN: The Epopteia (n. 114) 30-31.

${ }^{123}$ LeHMANN: The Epopteia (n. 114) 4 n. 3, 35-36; CONZE, A.: Reise auf den Inseln des Thrakischen Meeres. Amsterdam 1860; 59; LEHMANN: Samothrace: Third Report (n. 103) 5-6; LEHMANN: Samothrace: Fifth Report (n. 94) 20-27; MCCREDIE, J. R.: Samothrace: Supplementary Investigations, 1968-1977. Hesperia 48.1 (1979) 1-44, here 33.

${ }^{124}$ LEHMANN: The Epopteia (n. 114) 4 n. 3, 35-36: Analogous screening of a section of mystery shrines is mentioned in Pollux Onomasticon 3. 37 and Clement of Alexandria Protrepticus 2. 14: comparanda are suggested by the dedication of curtains in Lagina, at the temple of Hekate, and late antique taurobolia monuments from the sanctuary of the mother in Phlya. 


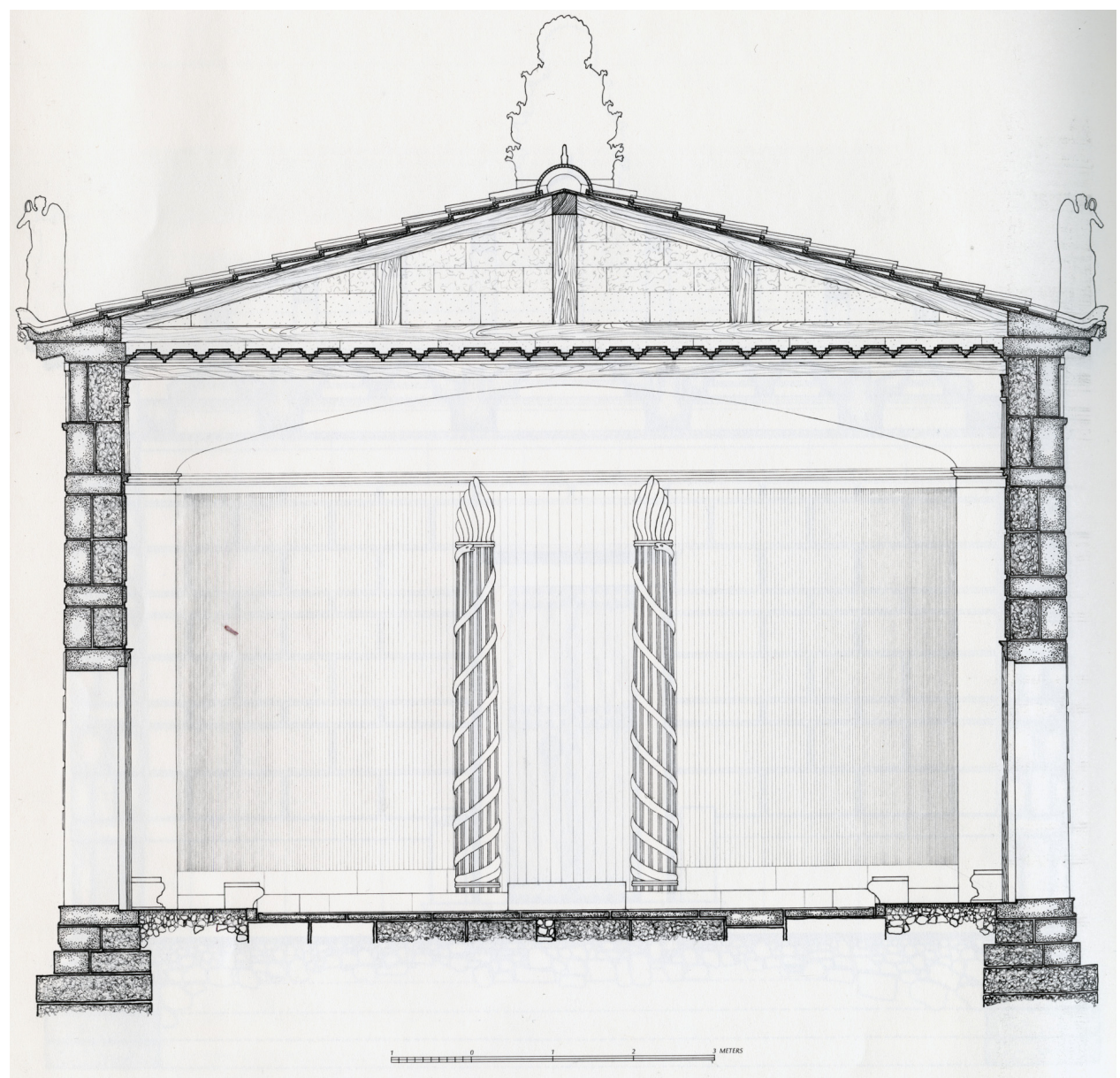

Fig. 12. Restored cross section of Hieron through the cella at the lateral doors, looking south (Lehmann, P. W. ET AL.: Samothrace. Vol. 3: The Hieron. Part 3: Plates. Princeton 1969, pl. CIV)

formed the vertical uprights on either side of the apse were retrieved in the form of fragments found near the center of the apse ${ }^{125}$ (figs 13a-b). These fragments suggest the monumental architectural counterpart of the doors depicted on the stele, and in a context in which the snakes and burning torch frame the "culminating acts of the liturgy'. ${ }^{126}$ The space for that culmination was created by a curved ceiling, low floor, and curved walls which suggest a grotto or cave-like structure. ${ }^{127}$ Aristotle describes

${ }^{125}$ LEHMANN: The Epopteia (n. 114) 31 and n. 144.

${ }^{126}$ LEHMANN: The Epopteia (n. 114) 32; LEHMANN ET AL.: Samothace (n. 114) 78, 135-138.

${ }^{127}$ LEHMANN: The Epopteia (n. 114) 36 cites analogies at Nemea, Seleucia, Miletos and Ostia; elaboration of a natural caves may be seen in the Kabeirion on Mt. Kynthos in Delos, with its bothros and eschara, on Delos at the sanctuary of Kybele and Atis, and at the Campus of the Great Mother of Ida at Ostia, where caryatid-like Pans guarded the entrance. 

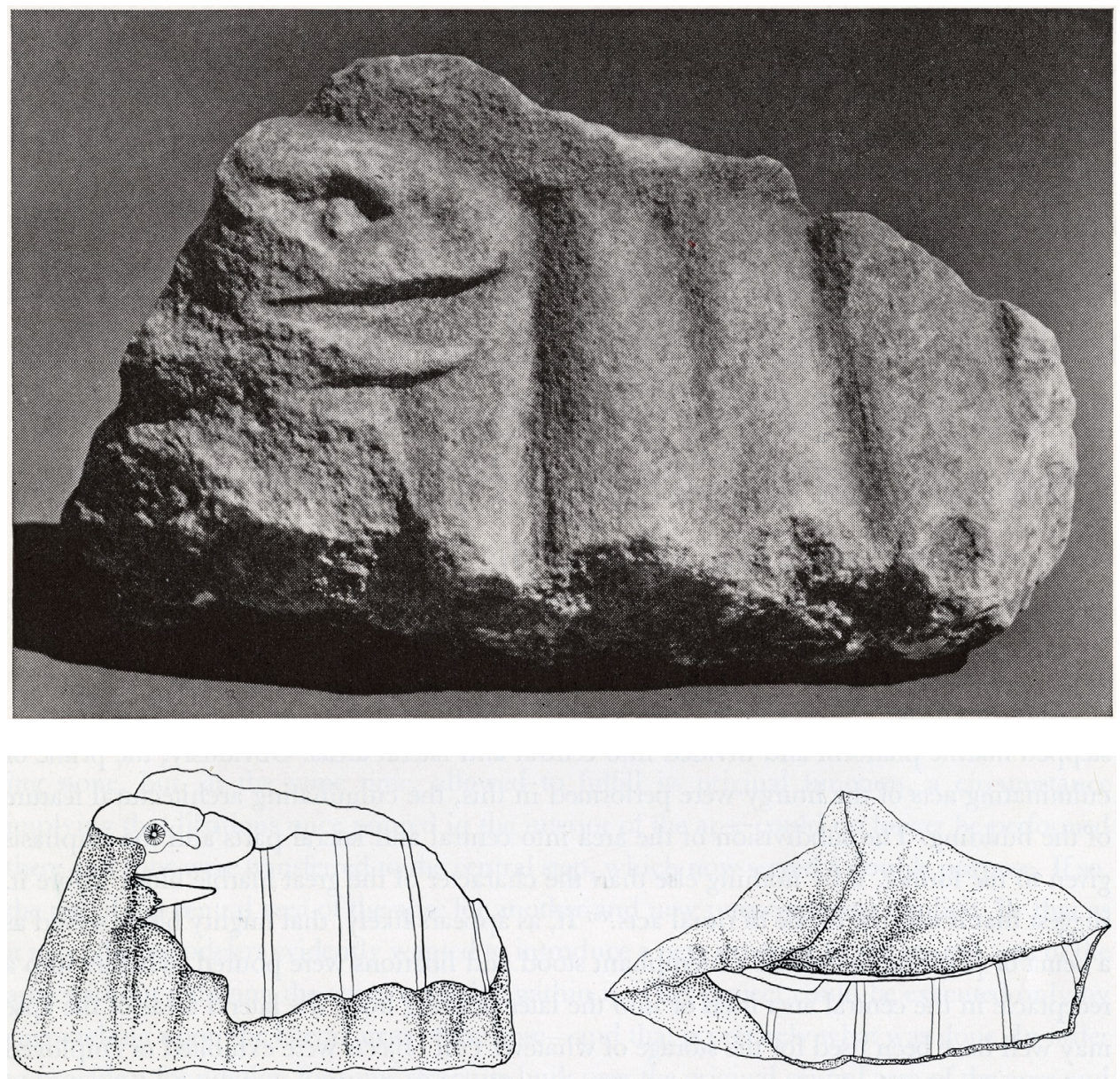

Figs 13a-b. Fragments of snake-wrapped torches from the Hieron (LEHMANN, P.W. ET AL.: Samothrace. Vol. 3: The Hieron. Part 3: Plates. Princeton 1969, 136, fig. 89)

the celebrations of the great mother in a cave on Lipara (de mirabilibus auscultationibus 101); Herodotus told accounts of Thracian Zalmoxis, who spent three years underground (4. 95). ${ }^{128}$ Our most vivid account comes from Apuleius' account of his descent, for initiation, into a semicircular crypt (Golden Ass 11. 25).

Within the Samothracian Hieron, we have no texts for enlightenment - but can note that the visitors to this space would encounter two architecturally realized junctures of fire and the chthonic. The first is the fire which would leap from the escharai in the center aisle; the second is the sculpted fire toward which the snakes ascend.

${ }^{128}$ Cf. Hesychius s.v. 'Kubela'; cf. Ustinova, Y.: Caves and the Ancient Greek Mind: Descending Underground in the Search for Ultimate Truth. Oxford 2009, 1-13, 100-108. 
Lehmann notes the correspondence between these snakes and those which flank the kerykeion of Hermes, engrave on a stele at the Anaktoron as the marker of a bilingual inscription which warns the uninitiated not to enter - signaling the ritual privileges attendant on access to the space beyond. ${ }^{129}$ Inside the Hieron, those snakes frame the curtain, behind which was an encounter with the chthonic force of the island itself. As the initiate moved into this hidden space, she or he would encounter that chthonic force through a series of architecturally realized semicircles: the bothros cut into the floor, the semicircular curve of the apse itself. An initiate who brought a Pythagorean perspective, or one prepared to encounter Dioscuri, would have in these forms the geometric evocation of the Dioscuri's myth of celestial ascent, set at the intersection of bedrock, chthonic snakes and permanently upright torches.

An encounter with twin lights which frame a closed entrance - whether a door or curtain - thus seems central to the experience of the Samothracian rites. Those lights have multiple pathways for engaging with the semantic range of the Dioscuri: as analogues to the island's Kabeiroi, as attendants of Cybele, as agents of Arsinoe's apotheosis, or framers of an initiate's culminating ritual moment. Nigidius raises the potential for those lights, as stars, to condense the tale of the Dioscuri's catasterism that most connected them to the island's promise of maritime safety. An instructive analogy comes from the Kabeirion of Lemnos. Here, the Kabeiroi were celebrated as the sons of Hephaistos, the divine embodiment of the metallurgy which was central to the island's economic success. ${ }^{130}$ Both Accius and Cicero suggest a central role for fire, Vulcan, and Prometheus in the rites. Accius sings, in the Philoctetes (F 525), of the vapors which emerge from Vulcan's temple in the woods of Lemnos, and a secret tale of the distribution of fire to man. Cicero suggests that these woods were the setting for the rites themselves (de natura deorum 1. 42. 119). Fragments of Aeschylus and Philostratos help confirm that the mystic fire of Lemnos was the fire of craftsmen and smiths, appropriate for the centrality of metallurgy to the island's economic success and identity. ${ }^{131}$ Nigidius' details of the Samothracian Dioscuri suggests that if the best export of resource-poor Samothrace was maritime safety, the twin stars of Dioscuri-Kabeiroi should be precisely those that protect travelers at sea.

\section{CONCLUSION: COMPARISON, METHOD, AND CONTEXT}

The superficial similarities between Samothracian Dioscuri and the Mithraic torchbearers are many. They share a mystic context, an iconography of shining torches, and an architectural function as the frame for an encounter with the divine. Both sets of

\footnotetext{
${ }^{129}$ LEHMANN: The Epopteia (n. 114) 40-41.

${ }^{130}$ NAKOU, G.: The Role of Poliochni and the North Aegean in the Development of Aegean Metallurgy. In Doumas C. - LA RosA, V. (edd): Poliochni e l'Antica Età del Bronzo nell'Egeo Settentionale. Convegno Internazionale, Atene, 22-25 Aprile 1996. Athens 1997, 634-648; DoumAS, C.: Poliochni: What Happened to Its Early Bronze Age Inhabitants? In Magna Grecia, Etruschi, Fenici. Atti del trentatreesimo convegno di studi sulla Magna Grecia, Taranto, 8-13 ottobre 1993. Taranto 1994, 51-58.

${ }^{131}$ BURKERT: Jason (n. 99).
} 
figures are tied to the journeys more than mortal - the torchbearers render experiential, for the Mithraic celebrants, the pathway through the stars, behind which may lie a hope of salvation. Samothrace's Dioscuri are put to a more pragmatic effect - the physical salvation of mariners in distress, for whom accounts of their aid to legendary travelers become paradigms of their own experience. Both sets of young men reveal the need for an approach which is flexible and polysemic: Beck's methodological call for an approach to Mithraic iconography which is nuanced and subtle is productively brought to the Samothracian mysteries, which are as poor in images as Mithraia are rich. And both Samothrace and the Mithraea - in the course of exploring these figures - highlight the extent to which the phenomenon of mystery initiation closed the gap between the gods and the initiate. Cult vessels from Mainz and Köln suggest initiates acting out the celestial trek which was drawn into the constellations of the tauroctony: the torchbearers' potential role in the story of human genesis and apogenesis is paralleled in the hopes articulated by the cosmic Dioscuri in the context of Roman funerals. In the Samothracian site, the Dioscuri are evoked aniconically through a series of images and architectural realizations. Initiates who shared Nigidius' outlook would draw physically close to the twinkling lights which guarded the mysteries, use their own lamps to illuminate their vision, and see, in the Hieron's apse, the culminating symbols of the rituals they would never reveal.

Unlike the torchbearers, the Dioscuri come to the island trailing Classical and Hellenistic narrative traditions. Nigidius' observations show the process of choosing from that broad range the elements most resonant with the rites as he knew them. His process of selection offers analogy to Octavian Zeno's Mithraeum, in which the images chosen, out of all the possibilities, allowed one Roman family to write their own identity in Mithraic terms. Nigidius represents not a family identity but the elite philosophical circles of late Republican Rome. The context of preservation for his Samothracian fragments highlights the cultural energy of Rome's engagement with astral mysticism. Nigidius is one of a select group of literate, philosophically inclined, upper class men among whom a robust attention to the stars was part of the model of cultivated society. ${ }^{132}$ An appetite for these astral conversations was not limited, however, to the literate few - as Pliny noted, the common people themselves interpreted the comet as a signal of Caesar's apotheosis ( $\mathrm{NH}$ 2. 93-94). Nor was it confined to the late Republic, as the literary record suggests. Poetically charming, scientifically inaccurate astronomy was part of the school curriculum through the imperial period and into late antiquity. This provides perhaps the most profound similarity between the torchbearers and the Dioscuri. Despite the distance in time and space between Samothrace and the Mithraia, the rituals shared a common context: the Roman eagerness to look to the stars for narratives which closed the gap between the mortal and divine. $^{133}$

${ }^{132}$ LE BOEUFFLE (n. 75) xvii.

${ }^{133}$ See CSAPO, E.: Star Choruses: Eleusis, Orphism, and New Musical Imagery and Dance. In ReVERMANN M. - WILSON, P. (eds): Performance, Iconography, Reception: Studies in Honour of Oliver Taplin. Oxford 2008, 262-290. 
Samothrace has a great distinction, however, from Mithras in the role it played in Roman cultural identity. In great contrast to the carefully constructed or maintained orientalism of the Mithraic caves, Romans expended great cultural energies in identifying the Samothracian rites as deeply, originally Roman. Nigidius' claims for the Dioscuri should be enrolled among these energies, despite their correspondence to both Greek traditions and to the material experience of the rites. In Greek sources, the Dioscuri came to the island only late. For Romans, the divine twins played multiple roles which positioned them at the heart of Roman power: as saviors at Lake Regillus, as analogies for imperial twins, as attendants to the emperor himself. ${ }^{134}$ Nigidius offers an analogous centrality for the twins in the Samothracian rites themselves a proposal which far exceeds any Greek claims, but would make a Roman visitor feel entirely at home.

Sandra Blakely

Department of Classics

Emory University

Atlanta, Georgia

USA

sblakel@emory.edu

${ }^{134}$ Nista, L. (ed.): Castores. L'immagine dei Dioscuri a Roma. Rome 1995; Poulson, B.: The Dioscuri and Ruler Ideology. SO 66 (1991) 110-146; REBEGGIANI, S.: Reading the Republican Forum: Virgil's Aeneid, the Dioscuri, and the Battle of Lake Regillus.' CP 108.1 (2013) 53-69. 
